\title{
Auriferous alkynylselenolatoalkylidynes
}

\author{
Benjamin J. Frogley, ${ }^{a}$ Anthony F. Hill*a and Chee S. Onn ${ }^{a}$ \\ The reaction of alkynylselenolatoalkylidynes $\left[\mathrm{W}(\equiv \mathrm{CSeC} \equiv \mathrm{CR})(\mathrm{CO})_{2}\left(\mathrm{Tp}^{*}\right)\right]\left(\mathrm{R}=\mathrm{SiMe}_{3}, \mathrm{Si}^{\mathrm{i} P r}, \mathrm{Ph}, p\right.$-tolyl, ${ }^{\mathrm{t}} \mathrm{Bu}, \mathrm{CPh}_{3}, \mathrm{SiPh}_{3}, \mathrm{GePh}{ }_{3}$; \\ $\mathrm{Tp}^{*}=$ hydrotris(3,5-dimethylpyrazol-1-yl)borate) with $[\mathrm{AuCl}(\mathrm{L})]\left(\mathrm{L}=\right.$ tetrahydrothiophene, $\left.\mathrm{SMe}_{2}\right)$ readily furnishes \\ heterobimetallic complexes $\left[\mathrm{WAu}(\mu-\mathrm{CSeC} \equiv \mathrm{CR}) \mathrm{Cl}(\mathrm{CO})_{2}\left(\mathrm{Tp}^{*}\right)\right]$ where gold $(\mathrm{I})$ chloride coordinates to the tungsten-carbon \\ multiple bond. Alternatively, desilylation of the $\mathrm{SiMe}_{3}$ complex $\left[\mathrm{W}(\equiv \mathrm{CSeC} \equiv \mathrm{CSiMe})(\mathrm{CO})_{2}\left(\mathrm{Tp}^{*}\right)\right]$ in the presence of a gold \\ phosphine complexes $\left[\mathrm{AuCl}\left(\mathrm{PR}_{3}{ }_{3}\right)\right]\left(\mathrm{R}^{\prime}=\mathrm{Ph}\right.$ or $\left.\mathrm{Cy}\right)$ furnishes the gold alkynyl derivatives, $\left[\mathrm{W}\left(\equiv \mathrm{CSeC} \equiv \mathrm{CAuPR}_{3}\right)(\mathrm{CO})_{2}\left(\mathrm{Tp}^{*}\right)\right]$.
}

\section{Introduction}

Connecting two metal centres by a single chain of carbon atoms ('carbon-wires') is of interest in the burgeoning field of molecular electronics, with particular emphasis on the nature of intermetallic communication. ${ }^{1}$ Our own focus has turned in recent times to the interruption of such chains by a main-group element, the argument being that electronic communication along the chain might be moderated (switched, amplified or attenuated) by exploiting the chemical behaviour of such elements as Lewis acids (group 13) or bases (group 15) towards extraneous chemical stimuli (Chart 1$).^{2}$
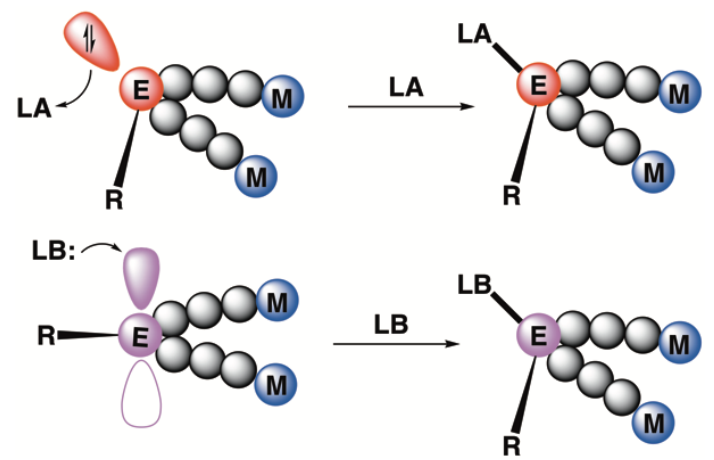

Chart 1. Schematic moderation of dimetallated carbon wires interrupted by heteroatoms (E). (a) Lewis basic (Groups 15,16) centre switched by appending Lewis Acid (LA). (b) Lewis acidic (Group 13) centre switching by appending Lewis base (LB).

The preparation of molecular models is all well and good, however reproducibly 'soldering' these intriguing species to macroscopic surfaces for interrogation presents a challenge that attracts intense study. Amongst the surfaces of interest, many are based on gold in various forms, be it electrodes, nanoparticles or STM probes, ${ }^{3}$ and the intimate nature of such junctions is of crucial importance for understanding properties. Accordingly, taking the recently described alkynylselenolatocarbynes $\left[\mathrm{W}(\equiv \mathrm{CSeC} \equiv \mathrm{CR})(\mathrm{CO})_{2}\left(\mathrm{Tp}^{*}\right)\right] \quad(\mathrm{R}=$ $\mathrm{SiMe}_{3}, \mathrm{Si}^{\mathrm{i} P P_{3}}, \mathrm{Ph}, p$-tolyl, ${ }^{t} \mathrm{Bu}, \mathrm{CPh}_{3}, \mathrm{SiPh}_{3}, \mathrm{GePh}_{3} ; \mathrm{Tp}^{*}=$ hydrotris(3,5-dimethylpyrazol-1-yl)borate) ${ }^{2 a}$ as exemplars of main-group element interrupted carbon chain components, we address herein the ways in which such species may interact with gold $(I)$ reagents, given they possess $\mathrm{W} \equiv \mathrm{C}$ and $\mathrm{C} \equiv \mathrm{C}$ triple bonds as well as alkynyl and alkylidynyl selenoether C-Se bonds, each of which are in principle capable of coordination to low-valent gold centres, be they molecular or superficial in nature. Previous investigations of alkynyselenolatocarbynes have explored the addition of metal fragments to the $\mathrm{C} \equiv \mathrm{C}$ but not $\mathrm{M} \equiv \mathrm{C}$ multiple bonds (Scheme 1).

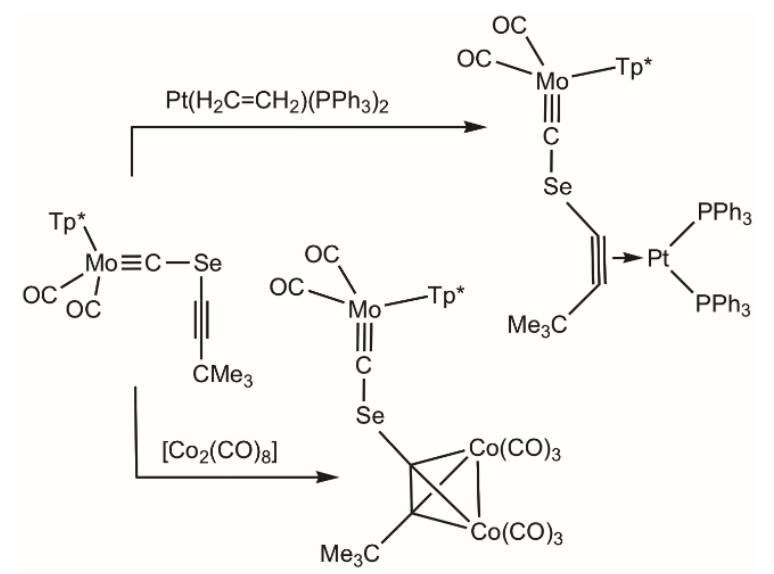

Scheme 1. Alkyne coordination of alkynylselenolatocarbynes.

Bridging transition-metal carbynes, where one or two metal centres are appended to metal-carbon triple bonds, form the basis of a number of fascinating assemblies. Following Roper and Wright's initial report of the addition of gold halides to the triple and double $\mathrm{OsC}$ bonds of $\left[\mathrm{Os}\left(\mathrm{ECC}_{6} \mathrm{H}_{4} \mathrm{Me}-\right.\right.$ 4) $\left.\mathrm{Cl}(\mathrm{CO})\left(\mathrm{PPh}_{3}\right)_{2}\right]^{4 \mathrm{a}}$ and $\left[\mathrm{OsCl}(\mathrm{NO})\left(=\mathrm{CH}_{2}\right)\left(\mathrm{PPh}_{3}\right)_{2}\right]$, ${ }^{4 \mathrm{~b}}$ respectively, Stone and co-workers made extensive use of this feature in the strategic construction of short polymetallic chains and rings. ${ }^{5}$ Among these, several were reported wherein a gold moiety bridges a hydrocarbyl-substituted molybdenum or tungsten alkylidyne, including elegant 'bow-tie' examples where two carbynes are bridged by a single gold atom (e.g. I, Chart 2). ${ }^{5 a, 5 d}$ 


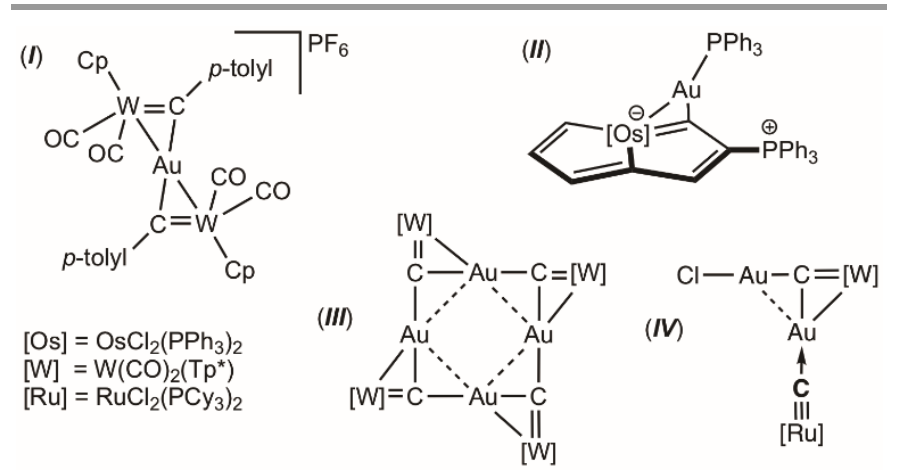

Chart 2. Examples of alkylidyne complexes where gold $(I)$ fragments have been coordinated to the carbyne bond. ${ }^{2 a, 4,6}$

The gold fragments were typically installed using a $[\mathrm{AuCl}(\mathrm{L})]$ reagent by either direct chloride displacement by an anionic alkylidyne or by halide abstraction using thallium(I) salts. A small number of other examples followed from similar procedures. ${ }^{6}$ Xia and co-workers have demonstrated that cyclic carbynes may also be susceptible towards gold(I) coordination and treatment of their osmapentalyne complex with [AuCl$\left(\mathrm{PPh}_{3}\right)$ ] and $\mathrm{NH}_{4} \mathrm{PF}_{6}$ gave the gold phosphine adduct (II, Chart 2). ${ }^{7}$ Finally, the stannylcarbyne $\left[\mathrm{W}\left(\equiv \mathrm{CSnMe}_{3}\right)(\mathrm{CO})_{2}\left(\mathrm{Tp}^{*}\right)\right]$ $\left(\mathrm{Tp}^{*}=\right.$ hydrotris(3,5-dimethylpyrazol-1-yl)borate) reacts with $\left[\mathrm{AuCl}\left(\mathrm{SMe}_{2}\right)\right]$ to furnish an octametallic 'golden ring' $\left[\mathrm{W}(\equiv \mathrm{CAu})(\mathrm{CO})_{2}\left(\mathrm{Tp}^{*}\right)\right]_{4}(\mathrm{III}$, Chart 2$)$, an eight-membered $\mathrm{C}_{4} \mathrm{Au}_{4}$ ring, held in place largely by aurophilic interactions. ${ }^{8 a}$ This unusual complex is only weakly associated and reacts reversibly with phosphines to rapidly generate the terminal gold species, $\left[\mathrm{W}\left(\equiv \mathrm{CAuPR}_{3}\right)(\mathrm{CO})_{2}\left(\mathrm{Tp}^{*}\right)\right] \quad(\mathrm{R}=\mathrm{Ph}, \mathrm{Et})$. A similar approach involving combination of $\left[\mathrm{W}\left(\equiv \mathrm{CSn}^{n} \mathrm{Bu}_{3}\right)(\mathrm{CO})_{2}\left(\mathrm{Tp}^{*}\right)\right]$ with $\left[\mathrm{Ru}(\mathrm{CAuCl}) \mathrm{Cl}_{2}\left(\mathrm{PCY}_{3}\right)_{2}\right]$ results in the formation of a rare bis(carbido) complex [WRuAu $\left.(\mu-\mathrm{C})_{2} \mathrm{Cl}_{2}(\mathrm{CO})_{2}\left(\mathrm{PCy}_{3}\right)_{2}\left(\mathrm{Tp}^{*}\right)\right]$ (IV, Chart 2) featuring two distinct carbido bridging modes. ${ }^{8 \mathrm{~b}}$

In the case of phosphinocarbynes $L_{n} M \equiv C P R_{2}$, coordination occurs preferentially at phosphorus, with subsequent coordination to the carbyne bond occurring only if excess $[\mathrm{AuCl}(\mathrm{THT})]$ (THT = tetrahydrothiophene) is added..$^{2 \mathrm{~b}, \mathrm{~g}}$ These represent the only examples of the addition of gold to heteroatom functionalised carbynes. Accordingly, the reactions of $\mathbf{2}$ with gold transfer reagents were explored.

\section{Results and discussion}

The reported chemistry of alkynylselenolatocarbynes is limited to the reactions of $\left[\mathrm{Mo}\left(\equiv \mathrm{CSeC} \equiv \mathrm{C}^{t} \mathrm{Bu}\right)(\mathrm{CO})_{2}\left(\mathrm{Tp}^{*}\right)\right]$ with $\left[\mathrm{CO}_{2}(\mathrm{CO})_{8}\right],\left[\mathrm{Pt}\left(\eta-\mathrm{C}_{2} \mathrm{H}_{4}\right)\left(\mathrm{PPh}_{3}\right)_{2}\right]$ and $\left[\mathrm{RhCl}\left(\mathrm{PPh}_{3}\right)_{3}\right]$, each of which eventually involve $\mathrm{C}-\mathrm{Se}$ bond cleavage. ${ }^{9}$ We presumed, correctly, that interactions with mild gold(I) reagents would be more likely to proceed with retention of the $\mathrm{WCSeC}_{2}$ spine of $\mathbf{2}$, given that alkyne coordination to $\mathrm{Au}(\mathrm{I})$ is typically weak and labile ${ }^{10}$ and because $A u(I)$ is not prone to (C-Se) oxidative addition processes. On treatment of the alkynylselenolatoalkylidyne $\left[\mathrm{W}\left(\equiv \mathrm{CSeC} \equiv \mathrm{CSiMe}_{3}\right)(\mathrm{CO})_{2}\left(\mathrm{Tp}^{*}\right)\right](\mathbf{2 a})$ with $[\mathrm{AuCl}(\mathrm{THT})]$ or $\left[\mathrm{AuCl}\left(\mathrm{SMe}_{2}\right)\right]$, the weakly coordinated thioether ligand is readily displaced and the $\mathrm{AuCl}$ fragment preferentially coordinates to the tungsten-carbon triple bond, furnishing the aurated derivative, [WAu( $\mu$ $\left.\mathrm{CSeC} \equiv \mathrm{CSiMe}_{3}\right) \mathrm{Cl}(\mathrm{CO})_{2}\left(\mathrm{Tp}^{*}\right)$ ] (3a, Scheme 2$)$, in high yield. This simple procedure is highly reliable and extends to give an entire suite of closely related derivatives, [WAu( $\mu$ $\left.\mathrm{CSeC} \equiv \mathrm{CR}) \mathrm{Cl}(\mathrm{CO})_{2}\left(\mathrm{Tp}^{*}\right)\right]\left(\mathrm{R}=\mathrm{Si}^{i} \mathrm{Pr}_{3} \mathbf{3 b} ; \mathrm{R}=\mathrm{Ph} \mathbf{3 c} ; \mathrm{R}=p\right.$-tolyl 3d; $\mathrm{R}$ $={ }^{t} \mathrm{Bu}$ 3e; $\mathrm{R}=\mathrm{CPh}_{3}$ 3f; $\mathrm{R}=\mathrm{SiPh}_{3}$ 3g; $\mathrm{R}=\mathrm{GePh}_{3}$ 3h) (Scheme 2), each of which were obtained as orange solids in good yield. In no instance was gold coordination to either the selenoether or the alkynyl group observed (vide infra). In the absence of chelation, ${ }^{11}$ selenoether coordination to gold is typically labile ${ }^{12}$ and the presence of two $s p-C$ substituents on the selenium of $2 \mathrm{a}$ would be expected to reduce its nucleophilicity.

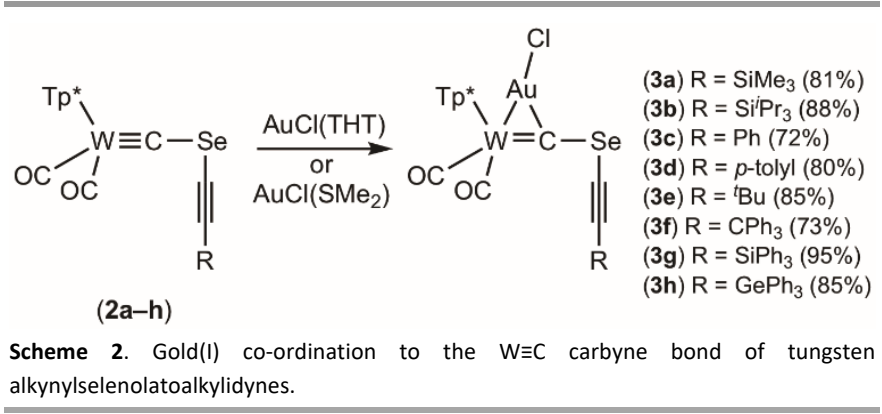

If care is taken to ensure the purity of the precursors, in addition to employing the precise stoichiometry and the exclusion of light, the only purification necessary to obtain elementally pure products is a simple filtration through diatomaceous earth and subsequent removal of the volatiles in vacuo. Prolonged stirring in solution and/or exposure to light typically results in decomposition into unidentified products and frequently coincides with the deposition of gold mirrors on glassware. If necessary, column chromatography (silica gel, petroleum ether $/ \mathrm{CH}_{2} \mathrm{Cl}_{2}$ as the eluent) can also be performed with only a minor reduction in product yield. In general, the use of $\left[\mathrm{AuCl}\left(\mathrm{SMe}_{2}\right)\right]$ was found to be preferable to [AuCl(THT)] simply because the greater volatility of dimethylsulfide aids in its subsequent removal so long as appropriate precautions are taken to manage its highly offensive odour.

Selected spectroscopic and structural data are presented in Table 1. Coordination of ' $\mathrm{AuCl}$ ' to the $\mathrm{W} \equiv \mathrm{C}$ bond has only a very minor influence on proton and carbon NMR chemical shifts. In the ${ }^{13} \mathrm{C}\left\{{ }^{1} \mathrm{H}\right\}$ NMR spectra of $3 a$, for example, the chemical shift of the carbyne carbon (236.4 ppm) is barely changed upon $\mathrm{AuCl}$ coordination compared to the precursor $(2 \mathbf{a}, 235.3 \mathrm{ppm})$. The largest difference, as observed for complex 3c (238.2 ppm) cf. 2c (236.3 ppm), is only $1.9 \mathrm{ppm}$. There is, however, a rather significant reduction in the magnitude of the coupling between tungsten and the carbyne carbon $\left({ }^{183} \mathrm{~W} I=1 / 2,14.3 \%\right.$ natural abundance). This reduction, from $223-227 \mathrm{~Hz}$ in $\mathbf{2 a - h}$ to $104-$ $107 \mathrm{~Hz}$ in $\mathbf{3 a}-\mathbf{h}$, is consistent with the increased coordination at the carbon with attendant reduction in the $s$-character of the bonds involved, though the adopted semi-bridging geometry means that this is not simply the conversion from $s p c f . s p^{2}$ hybridisation. Gold(I) coordination also has a moderate influence on chemical shifts in the ${ }^{77} \mathrm{Se}$ NMR spectra, which move from $\delta_{\mathrm{se}}=497-517$ in the precursors to $\delta_{\mathrm{se}}=574-599$ in the aurated adducts. 
$X$-ray quality single crystals were in most cases gratifyingly forthcoming. The molecular structures of $\mathbf{3 c}-\mathbf{3 h}$ have been determined and the geometries of $\mathbf{3 c}, \mathbf{3 e}, \mathbf{3 g}$ and $\mathbf{3 h}$ are shown in Figures 1-4, respectively. Those of $\mathbf{3 d}$ and $\mathbf{3 f}$, which are similar to $\mathbf{3 c}$ and $\mathbf{3 g}$, respectively, are depicted in the Electronic Supporting Information. Gold(I) coordination results in an elongation of the tungsten-carbon bond distances of $c a 0.1 \dot{A}$ (1.81-1.84 $\dot{A}$ for 2b, 2d, 2g, 2h cf. 1.88-1.91 $\dot{A}$ for 3c-h), consistent with a reduction in multiple bond character. The $\mathrm{W}-$ $\mathrm{C}-\mathrm{Se}$ angles are also significantly more bent upon $\mathrm{AuCl}$ incorporation, from $c a 170^{\circ}$ to $151-157^{\circ}$, though this falls short of what might be expected for a symmetrical carbyne bridge. The tert-butyl complex $\mathbf{3 e}$ is the only example where the alkynyl moiety is directed towards $\mathrm{AuCl}$ rather than away from it and the steric repulsion between the two is presumably the cause of its comparatively smaller $\mathrm{W}-\mathrm{C}-\mathrm{Se}$ angle of $144.2(3)^{\circ}$. This difference in orientation probably results to minimise crystal packing effects, which are frequently found to be significant in Tp*-ligated alkylidyne systems. ${ }^{13}$

\begin{tabular}{|c|c|c|c|c|c|c|}
\hline & $\begin{array}{c}\delta_{\equiv c^{a}} \\
(\mathrm{ppm})\end{array}$ & $\begin{array}{l}{ }^{1} J_{\mathrm{cw}^{b}} \\
(\mathrm{~Hz})\end{array}$ & $\begin{array}{c}\delta_{\mathrm{se}^{a}} \\
(\mathrm{ppm})\end{array}$ & $\begin{array}{l}r_{\mathrm{W}=\mathrm{C}} \\
(\dot{\mathrm{A}})\end{array}$ & $\begin{array}{c}\angle \text { wcse } \\
\left({ }^{\circ}\right)\end{array}$ & $\begin{array}{c}V \mathrm{co}^{\mathrm{c}} \\
\left(\mathrm{cm}^{-1}\right)\end{array}$ \\
\hline $3 a$ & 236.4 & 107 & 589 & & & 2015, 1935 \\
\hline $3 b$ & 235.9 & 106 & 588 & & & 2015, 1934 \\
\hline 3c & 238.2 & 104 & 579 & $1.898(5)$ & $153.3(3)$ & 2013, 1932 \\
\hline 3d & 238.8 & 106 & 580 & $1.902(13)$ & $151.4(7)$ & 2013,1932 \\
\hline $3 e$ & 239.1 & 106 & 574 & $1.905(5)$ & $144.2(3)$ & 2012,1932 \\
\hline $3 f$ & 237.3 & 106 & 581 & $1.884(7)$ & $157.1(4)$ & 2013,1932 \\
\hline 3g & 234.6 & 106 & 597 & $1.895(8)$ & $156.7(4)$ & 2016, 1935 \\
\hline $3 \mathrm{~h}$ & 235.7 & 107 & 599 & $1.884(6)$ & $156.7(4)$ & 2015,1935 \\
\hline $4 a$ & 243.5 & 222 & 512 & $1.816(11)$ & $170.4(7)$ & 1982,1890 \\
\hline $4 b$ & 245.1 & 222 & 513 & & & 1981,1889 \\
\hline
\end{tabular}

${ }^{a}$ Measured in $\mathrm{CDCl}_{3} .{ }^{b}$ Measured in $\mathrm{CDCl}_{3} .{ }^{c}$ Measured in $\mathrm{CH}_{2} \mathrm{Cl}_{2}$.

The W-Au (2.78-2.84 $\dot{A})$ and C1-Au (1.99-2.04 $\dot{A})$ distances are consistent with other tungsten alkylidynes containing bridging gold fragments, ${ }^{2 \mathrm{~g}, 5,6,8}$ the C-Se distances (1.82-1.89 $\dot{\mathrm{A}}$ ) are appropriate for single selenoether bonds and the $\mathrm{C}-\mathrm{Se}-\mathrm{C}$ angles $\left(99.3-102.1^{\circ}\right)$ are in good agreement with those previously reported for acyclic alkynylselenoethers $\mathrm{RC} \equiv \mathrm{CSeR}^{\prime}$ $\left(98-101^{\circ}\right) .{ }^{14}$ In all cases the $\mathrm{C}-\mathrm{Se}$ and $\mathrm{W}-\mathrm{Au}$ bonds are not orthogonal but rather the bonding is best described as semibridging in nature, a feature that is often encountered for carbyne ligands bridging to gold. ${ }^{15}$

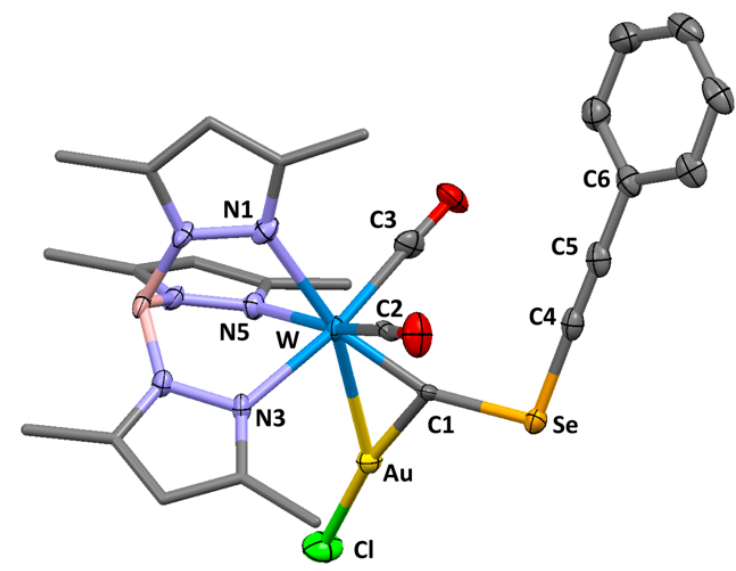

Figure 1. Molecular structure of 3c showing 50\% thermal probability ellipsoids. Pyrazolyl groups are simplified and hydrogen atoms are not shown for clarity. Selected distances $[\dot{A}]$ and angles [ $\left.{ }^{\circ}\right]: \mathrm{W}-\mathrm{C} 1$ 1.898(5), W-Au 2.7883(3), Au-Cl 2.2744(17), Au-C1 2.015(5), C1-Se 1.885(5), Se-C4 1.840(7), C4-C5 1.199(8), W-N1 2.221(5), W-N3 2.189(5), W-N5 2.202(5), W-C2 1.994(7), W-C3 2.012(6), W-C1-Se 153.3(3), W-C1-Au 90.8(2), C1-AuCl 170.66(16), C1-Se-C4 99.0(2), Se-C4-C5 175.1(5), C4-C5-C6 177.2(7).

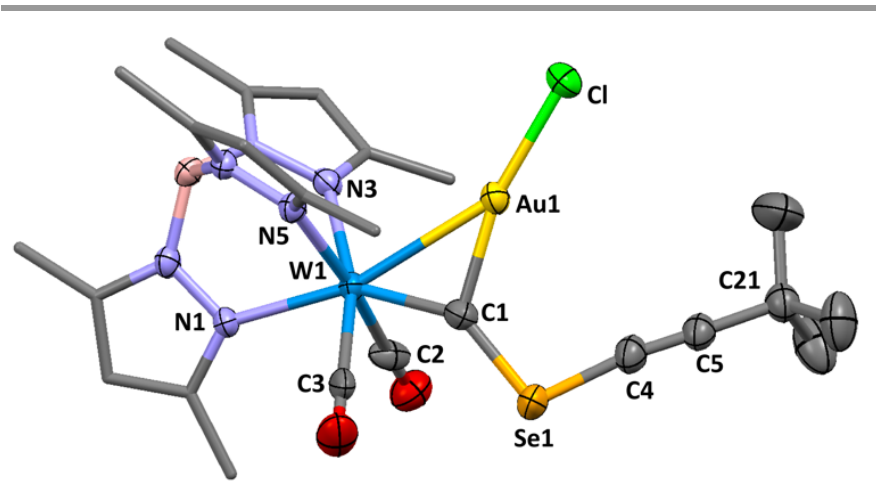

Figure 2. Molecular structure of $\mathbf{3 e}$ showing $50 \%$ thermal probability ellipsoids. Pyrazolyl groups are simplified and hydrogen atoms are not shown for clarity. Selected distances $[\dot{A}]$ and angles [ $\left.{ }^{\circ}\right]$ : W1-C1 1.905(5), W1-Au1 2.8418(3), C1-Au1 2.006(5), Au1-Cl1 2.2794(13), C1-Se1 1.875(5), Se1-C4 1.820(6), C4-C5 1.198(8), C5-C21 1.482(8), W1C1-Se1 144.2(3), W1-C1-Au1 93.2(2), C1-Se1-C4 101.8(2), Se1-C1-Au1 122.5(3), Se1C4-C5 172.3(5), C4-C5-C21 178.4(7).

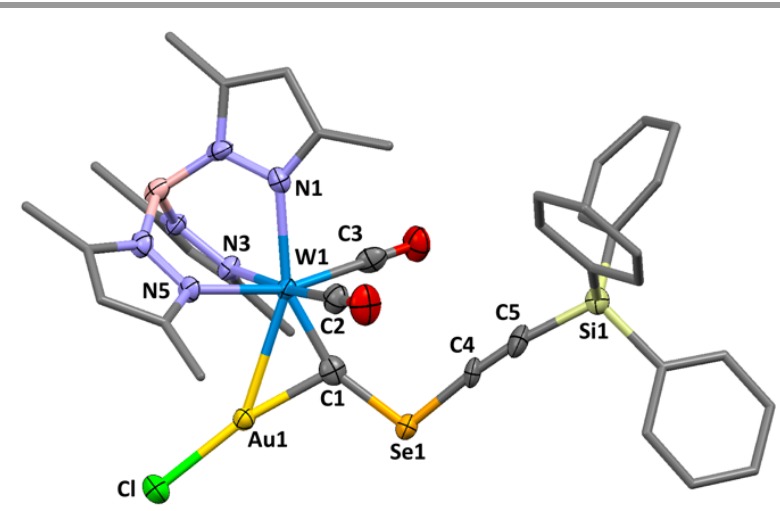

Figure 3. Molecular structure of $\mathbf{3 g}$ showing $50 \%$ thermal probability ellipsoids. Pyrazolyl groups and phenyl rings are simplified and hydrogen atoms are not shown for clarity. Selected distances $[\dot{A}]$ and angles [ $\left.{ }^{\circ}\right]$ : W1-C1 1.895(8), W1-Au1 2.7850(4), Au1-C1 2.034(7), Au1-Cl1 2.2679(19), C1-Se1 1.874(8), Se1-C4 1.840(7), C4-C5 1.194(12), C5Si1 1.836(9), W1-C1-Se1 156.7(4), W1-C1-Au1 90.2(3), W1-Au1-Cl1 146.69(6), C1Au1-Cl1 170.3(2), C1-Se1-C4 100.0(3), Se1-C4-C5 175.1(7), C4-C5-Si1 171.2(7). 


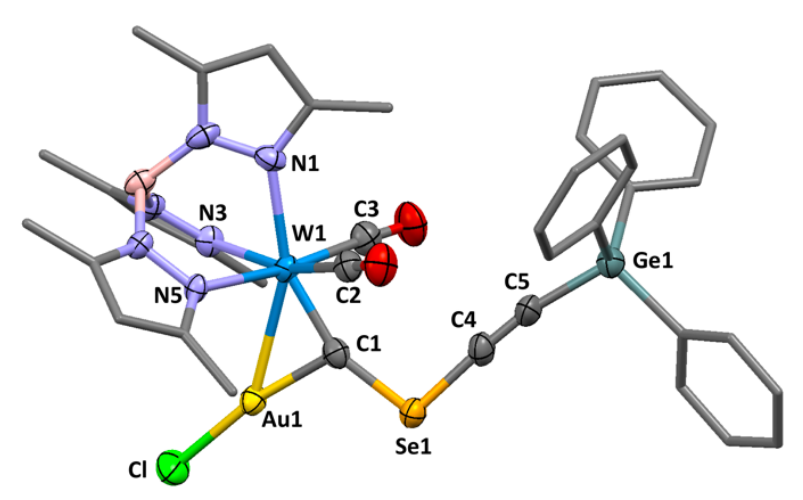

Figure 4. Molecular structure of $\mathbf{3 h}$ showing $50 \%$ thermal probability ellipsoids. Pyrazolyl groups and phenyl rings are simplified and hydrogen atoms are not shown for clarity. Selected distances $[\dot{A}]$ and angles [ ${ }^{\circ}$ ]: W1-C1 1.884(6), W1-Au1 2.7825(4), C1-Au1 2.032(6), Au1-Cl1 2.2651(17), C1-Se1 1.883(7), Se1-C4 1.838(7), C4-C5 1.188(10), C5Ge1 1.905(7), W1-C1-Se1 156.7(4), W1-C1-Au1 90.5(3), W1-Au1-Cl1 146.54(5), C1Se1-C4 100.1(3), Se1-C4-C5 176.7(6), C4-C5-Ge1 169.8(7).

Desilylation of the terminal trimethylsilyl group in the alkynylselenolatoalkylidyne $2 \mathrm{a}$ with $\left[\mathrm{NBu}_{4}\right] \mathrm{F}$ can serve as a means of generating the intermediate $\left[\mathrm{W}\left(\equiv \mathrm{CSeC} \equiv \mathrm{C}^{-}\right.\right.$ )$\left.(\mathrm{CO})_{2}\left(\mathrm{Tp}^{*}\right)\right]\left[\mathrm{NBu}_{4}\right]$ in situ, which can proceed to react with suitable electrophiles. ${ }^{2 a}$ Thus, when generated in the presence of $\left[\mathrm{AuCl}\left(\mathrm{PR}_{3}\right)\right]$, substitution of chloride occurs to furnish the terminal alkynyl gold phosphine derivatives, $\left[\mathrm{W}\left(\equiv \mathrm{CSeC} \equiv \mathrm{CAuPR}_{3}\right)(\mathrm{CO})_{2}\left(\mathrm{Tp}^{*}\right)\right](\mathrm{R}=\mathrm{Ph} \mathbf{4 a} ; \mathrm{R}=\mathrm{Cy} \mathbf{4 b}$, Scheme 3$)$. These two complexes were obtained in good purity and reasonable yields following a single precipitation from ethanol. This proved to be rather fortunate as both complexes $\mathbf{4 a}$ and $\mathbf{4 b}$ were found to be sensitive to chromatography and, when attempted on alumina or silica gel, only the parent ethynylselenolatoalkylidyne, $\left[\mathrm{W}(\equiv \mathrm{CSeC} \equiv \mathrm{CH})(\mathrm{CO})_{2}\left(\mathrm{Tp}^{*}\right)\right] \quad(\mathbf{2 i})$, ${ }^{2 a}$ was recovered, albeit in poor yield (ca 20\%). This hydrolysis side product is also obtained from the reaction of $\mathbf{2 a}$ and moist $\left[\mathrm{NBu}_{4}\right] \mathrm{F}$ in the absence of added electrophiles.<smiles></smiles><smiles></smiles>

(4a) $\mathrm{R}=\mathrm{Ph}(61 \%)$

(4b) $\mathrm{R}=\mathrm{Cy}(61 \%)$
Scheme 3. Formation of gold-terminated alkynylselenolatoalkylidynes.

The NMR spectral data for $\mathbf{4 a}$ and $\mathbf{4 b}$ are reassuringly similar to those of other reported alkynylselenolatoalkylidynes. ${ }^{2 a, 9 a}$ The carbyne carbons resonate at $\delta_{c}=243.5$ and $245.1 \mathrm{ppm}$, respectively, only very slightly downfield from those of $\mathbf{2 a - i}$ (234.0-240.1 ppm) and 3a-h (234.6-239.1 ppm). The coupling constants associated with the tungsten satellites for the carbyne carbon nuclei $\left({ }^{1} J_{\mathrm{CW}}=222 \mathrm{~Hz}\right.$ for both $4 \mathrm{a}$ and $\left.4 \mathrm{~b}\right)$ are similar in magnitude to complexes $\mathbf{2}$ and much larger than those of the $\eta^{2}-\mathrm{AuCl}$ complexes $\mathbf{3}$, supporting the formulation as terminal gold phosphine species where the $\mathrm{W} \equiv \mathrm{C}$ triple bond remains intact. The ${ }^{77} \mathrm{Se}$ chemical shifts $\left(\delta_{\mathrm{se}}=512\right.$ and 513 for 4a and $\mathbf{4 b}$, respectively) are also more closely associated with those of complexes 2 (494-525 ppm) rather than 3 (574-599 ppm) and despite a linear SeCCAuP spine, these resonances do not display resolvable coupling to phosphorus-31. The formulation is further supported by the acquisition of crystallographic data for $\mathbf{4 a}$, the results of which are summarised in Figure 7. The presence of the terminal gold triphenylphosphine moiety has only a minor influence on the structural parameters, which are all reassuringly similar to those of other reported alkynylselenolatoalkylidynes. ${ }^{2 a, 9 a}$

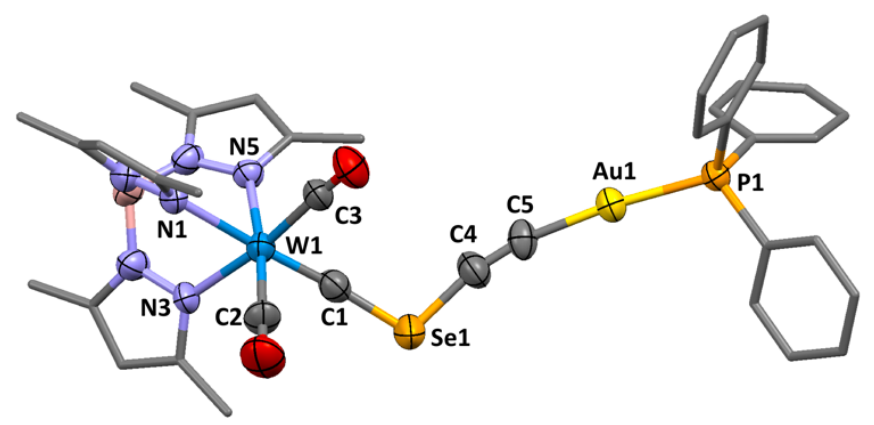

Figure 5. Molecular structure of 4a showing 50\% thermal probability ellipsoids. Pyrazolyl groups are simplified and hydrogen atoms are not shown for clarity. Selected distances $[\dot{A}]$ and angles [ $\left.{ }^{\circ}\right]$ : W1-C1 1.816(11), C1-Se1 1.843(11), Se1-C4 1.859(11), C4-C5 1.190(15), C5-Au 1.983(10), Au1-P1 2.276(2), W1-C1-Se1 170.4(7), C1-Se1-C4 104.3(5), Se1-C4-C5 167.3(12), C4-C5-Au1 167.5(11), C5-Au1-P1 173.8(3).

Gold alkynyls have recently attracted interest as intermediates in cross-coupling and other catalytic reactions, ${ }^{16}$ and there is some evidence that they may also be useful in this regard for alkylidyne couplings. ${ }^{8 a}$ Given the ease of their synthesis, complexes $\mathbf{4 a}$ and $\mathbf{4 b}$ may serve as useful substrates for reactions involving couplings or cyclizations of the alkynyl groups of alkynylselenolatoalkylidynes. This may be particularly valuable in situations where one or more reagents are sensitive towards the reaction conditions used for desilylation (if forming derivatives from $\mathbf{2 a}$ ) or deprotonation (if forming derivatives from $2 \mathbf{i}$ and a base such as ${ }^{n} \mathrm{BuLi}$ or $\mathrm{Li}\left[\mathrm{N}^{\mathrm{i}} \mathrm{Pr}_{2}\right]$ ).

\section{Conclusions}

The only previous examples of alkynylselenolatocarbynes involve the coordination of the alkynyl group to either ' $\mathrm{CO}_{2}(\mathrm{CO})_{6}$ ' or ' $\mathrm{Pt}\left(\mathrm{PPh}_{3}\right)_{2}$ ' units and in both cases, coordination is followed by $\mathrm{C}-\mathrm{Se}$ bond cleavage processes (Scheme 1). The results discussed above show that the alkynylselenolatocarbyne unit may indeed coordinate to gold(I) centres without rupture, either with adoption of a semi-bridging carbyne geometry ('metallacyclopropenene') or, alternatively, the gold may be installed as a terminus in heterobimetallic assemblies separated by a linear $\equiv \mathrm{C}-\mathrm{Se}-\mathrm{C} \equiv \mathrm{C}$ - bridge which is in contrast to the isomeric $\equiv \mathrm{C}-\mathrm{C} \equiv \mathrm{C}$-Se- bridge found in the previously reported tungsten-ruthenium selenolatopropynylidyne complex $\left[\mathrm{W}\left\{\equiv \mathrm{CC} \equiv \mathrm{CSeRu}\left(\mathrm{PPh}_{3}\right)_{2}\left(\eta-\mathrm{C}_{5} \mathrm{H}_{5}\right)\right\}(\mathrm{CO})_{2}\left(\mathrm{Tp}^{*}\right)\right] .{ }^{2 f}$ Taken together, these provide models for how a selenium-interrupted 'carbon wire' complex might be expected to bind to gold surfaces. 


\section{Experimental}

General Considerations. Unless otherwise stated, experimental work was carried out at room temperature under a dry and oxygen-free nitrogen atmosphere using standard Schlenk techniques with dried and degassed solvents.

NMR spectra were obtained at $25^{\circ} \mathrm{C}$ on a Bruker Avance 400 ( ${ }^{1} \mathrm{H}$ at $400.1 \mathrm{MHz},{ }^{13} \mathrm{C}$ at $100.6 \mathrm{MHz},{ }^{31} \mathrm{P}$ at $162.0 \mathrm{MHz}$ ), a Bruker Avance $600\left({ }^{1} \mathrm{H}\right.$ at $600.0 \mathrm{MHz},{ }^{13} \mathrm{C}$ at $\left.150.9 \mathrm{MHz}\right)$ or a Bruker Avance $700\left({ }^{1} \mathrm{H}\right.$ at $700.0 \mathrm{MHz},{ }^{13} \mathrm{C}$ at $\left.176.1 \mathrm{MHz}\right)$ spectrometers. Chemical shifts $(\delta)$ are reported in ppm and referenced to the solvent peak $\left({ }^{1} \mathrm{H},{ }^{13} \mathrm{C}\right)$ or externally referenced $\left(85 \% \mathrm{H}_{3} \mathrm{PO}_{4}\right.$ for ${ }^{31} \mathrm{P},(\mathrm{PhSe})_{2}$ for $\left.{ }^{77} \mathrm{Se}\right)$ with coupling constants given in $\mathrm{Hz}$. The multiplicities of NMR resonances are denoted by the abbreviations s (singlet), $d$ (doublet), $t$ (triplet), $m$ (multiplet), br (broad) and combinations thereof for more highly coupled systems. Where applicable, the stated multiplicity refers to that of the primary resonance exclusive of ${ }^{183} \mathrm{~W}$ satellites. In some cases, distinct peaks were observed in the ${ }^{1} \mathrm{H}$ and ${ }^{13} \mathrm{C}\left\{{ }^{1} \mathrm{H}\right\} \mathrm{NMR}$ spectra, but to the level of accuracy that is reportable (i.e., 2 decimal places for ${ }^{1} \mathrm{H}$ NMR, 1 decimal place for ${ }^{13} \mathrm{C} N M R$ ) they are reported as having the same chemical shift. The abbreviation ' $p z^{\prime}$ is used to refer to the pyrazolyl rings on the hydrotris(3,5-dimethylpyrazol-1-yl)borate (Tp*) ligand.

Infrared spectra were obtained using a Perkin-Elmer Spectrum One FT-IR spectrometer. The strengths of IR absorptions are denoted by the abbreviations vs (very strong), $\mathrm{s}$ (strong), m (medium), w (weak), sh (shoulder) and br (broad). Elemental microanalytical data were provided the London Metropolitan University. High-resolution electrospray ionisation mass spectrometry (ESI-MS) was performed by the ANU Research School of Chemistry mass spectrometry service with acetonitrile or methanol as the matrix.

Data for X-ray crystallography were collected with an Agilent Xcalibur CCD diffractomer using Mo-K $\alpha$ radiation $(\lambda=0.71073$ $\dot{A})$ or an Agilent SuperNova CCD diffractometer using $\mathrm{Cu}-\mathrm{K} \alpha$ radiation ( $\lambda=1.54184 \dot{A}$ ) using the CrysAlis PRO software. ${ }^{17}$ The structures were solved by direct or Patterson methods and refined by full-matrix least-squares on $F^{2}$ using the SHELXL programs ${ }^{18}$ and the WinGX ${ }^{19}$ or Olex2 software. ${ }^{20}$ Hydrogen atoms were located geometrically and refined using a riding model. Diagrams were produced using the CCDC visualisation program Mercury. ${ }^{18}$

The alkynylselenolatoalkylidynes $\mathbf{2 a} \mathbf{-} \mathbf{2} \mathbf{i}$ were prepared as reported previously. ${ }^{2 a}$ The complexes $[\mathrm{AuCl}(\mathrm{THT})]^{21}$ $\left[\mathrm{AuCl}\left(\mathrm{SMe}_{2}\right)\right]^{22}$ and $\left[\mathrm{AuCl}\left(\mathrm{PPh}_{3}\right)\right]^{23}$ were prepared according to literature methods. $\left[\mathrm{AuCl}\left(\mathrm{PC}_{3}\right)\right]$ was prepared by the reaction of an equimolar amount of $[\mathrm{AuCl}(\mathrm{THT})]$ and $\mathrm{PCy}_{3}$.

Synthesis of $\left[\mathrm{WAu}\left(\mu-\mathrm{CSeC} \equiv \mathrm{CSiMe}_{3}\right) \mathrm{Cl}(\mathrm{CO})_{2}\left(\mathrm{Tp}^{*}\right)\right]$ (3a). To a flask containing $2 \mathrm{a}(0.060 \mathrm{~g}, 0.083 \mathrm{mmol})$ and [AuCl(THT)] ( $0.027 \mathrm{~g}, 0.083 \mathrm{mmol}$ ) was added $\mathrm{CH}_{2} \mathrm{Cl}_{2}(5 \mathrm{~mL})$ and the resulting mixture was stirred for $30 \mathrm{~min}$, during which time the orange solution darkened. After this time the volatiles were removed in vacuo and the residue was subjected to column chromatography ( $10 \times 1 \mathrm{~cm}$ silica gel column), eluting with 2:1 $\mathrm{v} / \mathrm{v}$ petroleum ether $\left(40-60{ }^{\circ} \mathrm{C}\right) / \mathrm{CH}_{2} \mathrm{Cl}_{2}$. A bright orange band was collected, and the volatiles were removed under reduced pressure to give an orange microcrystalline solid of pure 3a (0.064 g, $0.067 \mathrm{mmol}, 81 \%)$. IR $\left(\mathrm{CH}_{2} \mathrm{Cl}_{2}, \mathrm{~cm}^{-1}\right): 2015,1935 v_{\mathrm{co}}{ }^{1} \mathrm{H}$ $\mathrm{NMR}\left(600 \mathrm{MHz}, \mathrm{CDCl}_{3}, 298 \mathrm{~K}\right): \delta_{\mathrm{H}}=0.23\left(\mathrm{~s}, 9 \mathrm{H}, \mathrm{SiCH}_{3}\right), 2.35(\mathrm{~s}$, $\left.3 \mathrm{H}, \mathrm{pzCH}_{3}\right), 2.35\left(\mathrm{~s}, 6 \mathrm{H}, \mathrm{pzCH}_{3}\right), 2.38\left(\mathrm{~s}, 9 \mathrm{H}, \mathrm{pzCH}_{3}\right), 5.93(\mathrm{~s}, 1$ $\mathrm{H}, \mathrm{pzCH}), 5.95(\mathrm{~s}, 2 \mathrm{H}, \mathrm{pzCH}) .{ }^{13} \mathrm{C}\left\{{ }^{1} \mathrm{H}\right\} \mathrm{NMR}\left(151 \mathrm{MHz}, \mathrm{CDCl}_{3}, 298\right.$ $\mathrm{K}): \delta_{\mathrm{C}}=0.0\left(\mathrm{SiCH}_{3}\right), 13.0,13.4,16.3,17.7\left(\mathrm{pzCH}_{3}\right), 83.8(\mathrm{SeC} \equiv \mathrm{CSi})$, $108.1,108.6$ (pzCH), 115.4 (SeC $\equiv C S i), 145.9,146.6,152.9,153.8$ $\left(\mathrm{pzCCH}_{3}\right), 215.4\left(\mathrm{CO}, 1 J_{\mathrm{wc}}=154\right), 236.4\left(\mathrm{~W}=\mathrm{C},{ }^{1} J_{\mathrm{wc}}=107 \mathrm{~Hz}\right)$. ${ }^{77} \mathrm{Se}\left\{{ }^{1} \mathrm{H}\right\} \mathrm{NMR}\left(76 \mathrm{MHz}^{\mathrm{CDCl}} \mathrm{CD}_{3}, 298 \mathrm{~K}, \delta\right): \delta_{\mathrm{se}}=589 . \mathrm{MS}(\mathrm{ESI}, \mathrm{m} / z)$ : Found: 964.0981. Calcd for $\mathrm{C}_{25} \mathrm{H}_{34} \mathrm{Au}^{11} \mathrm{BN}_{7} \mathrm{O}_{2}{ }^{80} \mathrm{SeSi}^{184} \mathrm{~W}$ [M$\left.\mathrm{Cl}+\mathrm{CH}_{3} \mathrm{CN}\right]^{+}$: 964.0968. Anal. Found: $\mathrm{C}, 28.98 ; \mathrm{H}, 3.31 ; \mathrm{N}, 8.80 \%$. Calcd for $\mathrm{C}_{23} \mathrm{H}_{31} \mathrm{AuBCIN}_{6} \mathrm{O}_{2} \mathrm{SeSiW}$ : C, 28.85; $\mathrm{H}, 3.26 ; \mathrm{N}, 8.78 \%$.

Synthesis of $\left[\mathrm{WAu}\left(\mu-\mathrm{CSeC} \equiv \mathrm{CSi}^{i} \mathrm{Pr}_{3}\right) \mathrm{Cl}(\mathrm{CO})_{2}\left(\mathrm{Tp}^{*}\right)\right]$ (3b). To a flask containing $2 \mathrm{~b}(0.036 \mathrm{~g}, 0.044 \mathrm{mmol})$ and [AuCl(THT)] ( $0.014 \mathrm{~g}, 0.048 \mathrm{mmol}$ ) was added $\mathrm{CH}_{2} \mathrm{Cl}_{2}(5 \mathrm{~mL})$ and the resulting mixture was stirred for $30 \mathrm{~min}$, during which time the orange solution darkened. The mixture was filtered through diatomaceous earth and the filtrate was dried under reduced pressure to give an orange solid of pure $\mathbf{3 b}(0.041 \mathrm{~g}, 0.039$ mmol, 88\%). IR $\left(\mathrm{CH}_{2} \mathrm{Cl}_{2}, \mathrm{~cm}^{-1}\right): 2015,1934 v_{\mathrm{co}}{ }^{1} \mathrm{H}$ NMR (700 $\mathrm{MHz}, \mathrm{CDCl}_{3}, 298 \mathrm{~K}$ ): $\delta_{\mathrm{H}}=1.11$ ( 2 x overlapping s, $21 \mathrm{H}, \mathrm{SiCH}$ ), 2.34 $\left(\mathrm{s}, 3 \mathrm{H}, \mathrm{pzCH}_{3}\right), 2.38\left(\mathrm{~s}, 6 \mathrm{H}, \mathrm{pzCH}\right.$ ) $, 2.46\left(\mathrm{~s}, 3 \mathrm{H}, \mathrm{pzCH}_{3}\right), 2.49$ (s, $6 \mathrm{H}, \mathrm{pzCH}$ ) $, 5.92(\mathrm{~s}, 1 \mathrm{H}, \mathrm{pzCH}), 5.95(\mathrm{~s}, 2 \mathrm{H}, \mathrm{pzCH}) .{ }^{13} \mathrm{C}\left\{{ }^{1} \mathrm{H}\right\} \mathrm{NMR}$ $\left(176 \mathrm{MHz}, \mathrm{CDCl}_{3}, 298 \mathrm{~K}\right): \delta_{\mathrm{C}}=11.7(\mathrm{SiCH}), 13.0,13.4,16.4,17.7$ $\left(\mathrm{pzCH}_{3}\right), 18.9\left(\mathrm{SiCHCH}_{3}\right), 84.2(\mathrm{SeC} \equiv \mathrm{C}), 108.1,108.5(\mathrm{pzCH})$, $112.5(\mathrm{SeC} \equiv C), 146.0,146.6,153.0,153.8\left(\mathrm{pzCCH}_{3}\right), 215.3$ (CO, $\left.{ }^{1} J_{\mathrm{WC}}=156\right), 235.9\left(\mathrm{~W}=\mathrm{C},{ }^{1} \mathrm{~J}_{\mathrm{WC}}=106 \mathrm{~Hz}\right) .{ }^{77} \mathrm{Se}\left\{{ }^{1} \mathrm{H}\right\} \mathrm{NMR}(76 \mathrm{MHz}$, $\left.\mathrm{CDCl}_{3}, 298 \mathrm{~K}\right): \delta_{\mathrm{se}}=588$. MS (ESI, $\left.\mathrm{m} / z\right)$ : Found: 1065.1206 . Calcd for $\mathrm{C}_{29} \mathrm{H}_{43} \mathrm{Au}^{11} \mathrm{~B}^{35} \mathrm{ClN}_{6} \mathrm{NaO}_{2}{ }^{80} \mathrm{SeSi}^{184} \mathrm{~W} \quad[\mathrm{M}+\mathrm{Na}]^{+}: \quad$ 1065.1240. Anal. Found: $\mathrm{C}, 31.03 ; \mathrm{H}, 3.99 ; \mathrm{N}, 7.67 \%$. Calcd for $\mathrm{C}_{29} \mathrm{H}_{43} \mathrm{AuBCIN}_{6} \mathrm{O}_{2} \mathrm{SeSiW} . \mathrm{CHCl} 3: \mathrm{C}, 31.03 ; \mathrm{H}, 3.82 ; \mathrm{N}, 7.24 \%$.

Synthesis of $\left[\mathrm{WAu}(\mu-\mathrm{CSeC} \equiv \mathrm{CPh}) \mathrm{Cl}(\mathrm{CO})_{2}\left(\mathrm{Tp}^{*}\right)\right]$ (3c). To a flask containing $2 \mathrm{c}(0.040 \mathrm{~g}, 0.055 \mathrm{mmol})$ and $[\mathrm{AuCl}(\mathrm{THT})](0.018$ g, $0.056 \mathrm{mmol}$ ) was added $\mathrm{CH}_{2} \mathrm{Cl}_{2}(5 \mathrm{~mL})$ and the resulting mixture was stirred for $30 \mathrm{~min}$, during which time the orange solution darkened. After this time the volatiles were removed in vacuo and the residue was subjected to column chromatography (10 $\times 1 \mathrm{~cm}$ silica gel column), eluting initially with petroleum ether $\left(40-60{ }^{\circ} \mathrm{C}\right)$ followed by $1: 1 \mathrm{v} / \mathrm{v}$ petrol $/ \mathrm{CH}_{2} \mathrm{Cl}_{2}$. A bright orange band was collected, and the volatiles were removed under reduced pressure to give an orange microcrystalline solid of pure $3 \mathrm{c}(0.038 \mathrm{~g}, 0.040 \mathrm{mmol}$, 72\%). IR $\left(\mathrm{CH}_{2} \mathrm{Cl}_{2}, \mathrm{~cm}^{-1}\right): 2013,1932 v_{\mathrm{CO}}{ }^{1} \mathrm{H} \mathrm{NMR}(700 \mathrm{MHz}$, $\left.\mathrm{CDCl}_{3}, 298 \mathrm{~K}\right): \delta_{\mathrm{H}}=2.29\left(\mathrm{~s}, 3 \mathrm{H}, \mathrm{pzCH}_{3}\right), 2.33\left(\mathrm{~s}, 3 \mathrm{H}, \mathrm{pzCH}_{3}\right], 2.38$ $\left(\mathrm{s}, 6 \mathrm{H}, \mathrm{pzCH}_{3}\right), 2.52\left(\mathrm{~s}, 6 \mathrm{H}, \mathrm{pzCH}_{3}\right), 5.87(\mathrm{~s}, 1 \mathrm{H}, \mathrm{pzCH}), 5.96(\mathrm{~s}, 2$ $\mathrm{H}, \mathrm{pzCH}), 7.34\left[\mathrm{~m}, 3 \mathrm{H}, \mathrm{H}^{2,4,6}\left(\mathrm{C}_{6} \mathrm{H}_{5}\right)\right], 7.53\left[\mathrm{~m}, 2 \mathrm{H}, \mathrm{H}^{3,5}\left(\mathrm{C}_{6} \mathrm{H}_{5}\right)\right]$. ${ }^{13} \mathrm{C}\left\{{ }^{1} \mathrm{H}\right\} \mathrm{NMR}\left(176 \mathrm{MHz}, \mathrm{CDCl}_{3}, 298 \mathrm{~K}\right): \delta_{\mathrm{H}}=13.0,13.4,16.0,17.8$ $\left(\mathrm{pzCH}_{3}\right), 70.1(\mathrm{SeC} \equiv \mathrm{C}), 106.7(\mathrm{SeC} \equiv C), 108.2,108.6(\mathrm{pzCH}), 122.8$ $\left[\mathrm{C}^{1}\left(\mathrm{C}_{6} \mathrm{H}_{5}\right)\right], 128.7\left[\mathrm{C}^{2,6}\left(\mathrm{C}_{6} \mathrm{H}_{5}\right)\right], 129.3\left[\mathrm{C}^{4}\left(\mathrm{C}_{6} \mathrm{H}_{5}\right)\right], 132.2\left[\mathrm{C}^{3,5}\left(\mathrm{C}_{6} \mathrm{H}_{5}\right)\right]$, $146.0,146.6,153.0,153.7\left(\mathrm{pzCCH}_{3}\right), 215.8\left(\mathrm{CO},{ }^{1} J_{\mathrm{wC}}=155\right)$, $238.2\left(\mathrm{~W}=\mathrm{C},{ }^{1} J_{\mathrm{WC}}=104 \mathrm{~Hz}\right) .{ }^{77} \mathrm{Se}\left\{{ }^{1} \mathrm{H}\right\} \mathrm{NMR}\left(76 \mathrm{MHz}, \mathrm{CDCl}_{3}, 298\right.$ $\mathrm{K}): \delta_{\mathrm{se}}=579$. $\mathrm{MS}(\mathrm{ESI}, \mathrm{m} / z)$ : Found: 985.0209. Calcd for $\mathrm{C}_{26} \mathrm{H}_{27} \mathrm{Au}^{11} \mathrm{~B}^{35} \mathrm{ClN}_{6} \mathrm{NaO}_{2}{ }^{80} \mathrm{Se}^{184} \mathrm{~W} \quad[\mathrm{M}+\mathrm{Na}]^{+}:$985.0224. Found: 968.0911. Calcd for $\mathrm{C}_{28} \mathrm{H}_{30} \mathrm{AuBN}_{7} \mathrm{O}_{2} \mathrm{SeW} \quad\left[\mathrm{M}-\mathrm{Cl}+\mathrm{CH}_{3} \mathrm{CN}\right]^{+}$: 968.0914. Anal. Found: C, 32.59; H, 2.81; N, 8.65\%. Calcd for $\mathrm{C}_{26} \mathrm{H}_{27} \mathrm{AuBClN}{ }_{6} \mathrm{O}_{2} \mathrm{SeW}$ : C, 32.48; H, 2.83; N, 8.74\%. Crystals 
suitable for structure determination were grown by slow evaporation of a $\mathrm{CH}_{2} \mathrm{Cl}_{2} /$ n-hexane mixture. Crystal data for $\mathrm{C}_{26} \mathrm{H}_{27} \mathrm{AuBCIN}_{6} \mathrm{O}_{2} \mathrm{SeW}: M_{\mathrm{w}}=961.57 \mathrm{gmol}^{-1}$, monoclinic, space group $P 2_{1} / \mathrm{n}$ (No. 14), $a=13.8448(5), b=11.0261(2), c=$ 20.0540 (7) $\AA, \beta=108.061(4)^{\circ}, V=2910.48(17) \AA^{3}, Z=4, T=$ $150.0(1) \mathrm{K}, \mu($ Mo K $\alpha)=10.362 \mathrm{~mm}^{-1}, D_{\text {calc }}=2.194 \mathrm{Mgm}^{-3}, 11992$ reflections measured $\left(7.05^{\circ} \leq 2 \Theta \leq 58.42^{\circ}\right), 6609$ unique $\left(R_{\text {int }}=\right.$ $\left.0.0338, R_{\text {sigma }}=0.0615\right)$ which were used in all calculations. The final $R_{1}$ was $0.0356(I>2 \sigma(I))$ and $w R_{2}$ was 0.0729 (all data) for 362 refined parameters with 0 restraints. CCDC 1911592.

Synthesis of $\left[\mathrm{WAu}\left(\mu-\mathrm{CSeC} \equiv \mathrm{CC}_{6} \mathrm{H}_{4} \mathrm{Me}-4\right) \mathrm{Cl}(\mathrm{CO})_{2}\left(\mathrm{Tp}^{*}\right)\right]$ (3d). To a flask containing $\mathbf{2 d}(0.040 \mathrm{~g}, 0.054 \mathrm{mmol})$ and [AuCl(THT)] ( $0.019 \mathrm{~g}, 0.059 \mathrm{mmol})$ was added $\mathrm{CH}_{2} \mathrm{Cl}_{2}(5 \mathrm{~mL})$ and the resulting mixture was stirred for $30 \mathrm{~min}$, during which time the orange solution darkened. After this time the volatiles were removed in vacuo and the residue was subjected to column chromatography (10 $\times 1 \mathrm{~cm}$ silica gel column), eluting initially with petroleum ether $\left(40-60{ }^{\circ} \mathrm{C}\right)$ followed by $1: 1 \mathrm{v} / \mathrm{v}$ petrol $/ \mathrm{CH}_{2} \mathrm{Cl}_{2}$. A slow-moving, bright orange band was collected and the volatiles were removed under reduced pressure to give an orange solid of pure $3 d(0.042 \mathrm{~g}, 0.043 \mathrm{mmol}, 80 \%)$. IR $\left(\mathrm{CH}_{2} \mathrm{Cl}_{2}, \mathrm{~cm}^{-1}\right)$ : 2013, 1932 vco. ${ }^{1} \mathrm{H} \mathrm{NMR}\left(700 \mathrm{MHz}, \mathrm{CDCl}_{3}, 298 \mathrm{~K}\right)$ : $\delta_{\mathrm{H}}=2.29\left(\mathrm{~s}, 3 \mathrm{H}, \mathrm{pzCH}_{3}\right), 2.33\left(\mathrm{~s}, 3 \mathrm{H}, \mathrm{pzCH}_{3}\right), 2.36(\mathrm{~s}, 3 \mathrm{H}$, $\left.\mathrm{C}_{6} \mathrm{H}_{4} \mathrm{CH}_{3}\right), 2.37\left(\mathrm{~s}, 6 \mathrm{H}, \mathrm{pzCH}_{3}\right), 2.51\left(\mathrm{~s}, 6 \mathrm{H}, \mathrm{pzCH}_{3}\right), 5.87(\mathrm{~s}, 1 \mathrm{H}$, $\mathrm{pzCH}), 5.96(\mathrm{~s}, 2 \mathrm{H}, \mathrm{pzCH}), 7.14\left[\mathrm{~d},{ }^{3}{ }_{\mathrm{HH}}=7.6,2 \mathrm{H}, \mathrm{H}^{3,5}\left(\mathrm{C}_{6} \mathrm{H}_{4}\right)\right]$, $7.42\left[\mathrm{~d},{ }^{3} \mathrm{~J}_{\mathrm{HH}}=7.6 \mathrm{~Hz}, 2 \mathrm{H}, \mathrm{H}^{2,6}\left(\mathrm{C}_{6} \mathrm{H}_{4}\right)\right] .{ }^{13} \mathrm{C}\left\{{ }^{1} \mathrm{H}\right\} \mathrm{NMR}(176 \mathrm{MHz}$, $\left.\mathrm{CDCl}_{3}, 298 \mathrm{~K}\right): \delta_{\mathrm{C}}=13.0,13.4,16.0,17.8\left(\mathrm{pzCH}_{3}\right), 21.9\left(\mathrm{C}_{6} \mathrm{H}_{4} \mathrm{CH}_{3}\right)$, $69.2(\mathrm{SeC} \equiv \mathrm{C}), \quad 106.7$ ( $\mathrm{SeC} \equiv C), \quad 108.1,108.6(\mathrm{pzCH}), 119.8$ $\left[\mathrm{C}^{1}\left(\mathrm{C}_{6} \mathrm{H}_{4}\right)\right], 129.4\left[\mathrm{C}^{3,5}\left(\mathrm{C}_{6} \mathrm{H}_{4}\right)\right], 132.2\left[\mathrm{C}^{2,6}\left(\mathrm{C}_{6} \mathrm{H}_{4}\right)\right], 139.7\left[\mathrm{C}^{4}\left(\mathrm{C}_{6} \mathrm{H}_{4}\right)\right]$, 146.0, 146.6, 153.0, $153.7\left(\mathrm{pzCCH}_{3}\right), 215.8\left(\mathrm{CO},{ }^{1} J_{\mathrm{wc}}=155\right)$, $238.8\left(\mathrm{~W}=\mathrm{C},{ }^{1} \mathrm{~J}_{\mathrm{WC}}=106 \mathrm{~Hz}\right) .{ }^{77} \mathrm{Se}\left\{{ }^{1} \mathrm{H}\right\} \mathrm{NMR}\left(76 \mathrm{MHz}, \mathrm{CDCl}_{3}, 298\right.$ $\mathrm{K}): \delta_{\mathrm{Se}}=580$. MS (ESI, $\left.m / z\right)$ : Found: 980.1058. Calcd for $\mathrm{C}_{29} \mathrm{H}_{32} \mathrm{Au}^{11} \mathrm{BN}_{7} \mathrm{NaO}_{2}{ }^{80} \mathrm{Se}^{184} \mathrm{~W}$ [M-Cl$\left.+\mathrm{CH}_{3} \mathrm{CN}\right]^{+}$: 980.1099. Anal. Found: $\mathrm{C}$, 33.15; $\mathrm{H}, 3.10 ; \mathrm{N}, \quad 8.50 \%$. Calcd for $\mathrm{C}_{27} \mathrm{H}_{29} \mathrm{AuBCIN} \mathrm{O}_{2} \mathrm{SeW}: \mathrm{C}, 33.24 ; \mathrm{H}, 3.00 ; \mathrm{N}, 8.61 \%$. Crystals suitable for structure determination were grown by slow evaporation of a $\mathrm{CH}_{2} \mathrm{Cl}_{2} / n$-hexane mixture and proved to be a dichloromethane solvate. Crystal data for $\mathrm{C}_{27} \mathrm{H}_{29} \mathrm{AuBCIN} \mathrm{O}_{2} \mathrm{SeW} .\left(\mathrm{CH}_{2} \mathrm{Cl}_{2}\right)_{0.5}: M_{\mathrm{w}}=1018.06 \mathrm{gmol}^{-1}$, triclinic, space group $P-1$ (No. 2), $a=9.9498(4), b=17.1859(10), c=$ 20.7731(8) $\AA, \alpha=105.918(4)^{\circ}, \beta=90.589(3)^{\circ}, \gamma=91.467(4)^{\circ}, V=$ 3414.2(3) $\AA^{3}, Z=4, T=150.0$ (1) $\mathrm{K}, \mu($ Mo $\mathrm{K} \alpha)=8.914 \mathrm{~mm}^{-1}$, $D_{\text {calc }}=1.981 \mathrm{Mgm}^{-3}, 23182$ reflections measured $\left(6.622^{\circ} \leq 2 \Theta \leq\right.$ $\left.52.744^{\circ}\right), 13856$ unique $\left(R_{\text {int }}=0.0443, R_{\text {sigma }}=0.0856\right)$ which were used in all calculations. The final $R_{1}$ was $0.0670(I>2 \sigma(I))$ and $w R_{2}$ was 0.1547 (all data) for 762 refined parameters with 0 restraints. CCDC 1911593.

Synthesis of $\left[\mathrm{WAu}\left(\mu-\mathrm{CSeC} \equiv \mathrm{C}^{t} \mathrm{Bu}\right) \mathrm{Cl}(\mathrm{CO})_{2}\left(\mathrm{Tp}^{*}\right)\right]$ (3e). To a flask containing $2 \mathrm{e}(0.015 \mathrm{~g}, 0.021 \mathrm{mmol})$ and $\left[\mathrm{AuCl}\left(\mathrm{SMe}_{2}\right)\right]$ ( $0.014 \mathrm{~g}, 0.048 \mathrm{mmol})$ was added $\mathrm{CH}_{2} \mathrm{Cl}_{2}(5 \mathrm{~mL})$ and the resulting mixture was stirred for $30 \mathrm{~min}$, during which time the orange solution darkened. The mixture was filtered through diatomaceous earth and the filtrate was dried under reduced pressure to give an orange solid of pure 3 e $(0.017 \mathrm{~g}, 0.018$ $\mathrm{mmol}, 85 \%)$. IR $\left(\mathrm{CH}_{2} \mathrm{Cl}_{2}, \mathrm{~cm}^{-1}\right): 2012,1932 \mathrm{v}_{\mathrm{co}} .{ }^{1} \mathrm{H}$ NMR (700 $\left.\mathrm{MHz}, \mathrm{CDCl}_{3}, 298 \mathrm{~K}\right): \delta_{\mathrm{H}}=1.31\left(\mathrm{~s}, 9 \mathrm{H}, \mathrm{C} \equiv \mathrm{CCCH}_{3}\right), 2.34(\mathrm{~s}, 3 \mathrm{H}$, $\left.\mathrm{pzCH}_{3}\right), 2.37\left(\mathrm{~s}, 6 \mathrm{H}, \mathrm{pzCH}_{3}\right), 2.49\left(\mathrm{~s}, 9 \mathrm{H}, \mathrm{pzCH}_{3}\right), 5.92(\mathrm{~s}, 1 \mathrm{H}$,
$\mathrm{pzCH}), 5.95(\mathrm{~s}, 2 \mathrm{H}, \mathrm{pzCH}) .{ }^{13} \mathrm{C}\left\{{ }^{1} \mathrm{H}\right\} \mathrm{NMR}\left(176 \mathrm{MHz}, \mathrm{CDCl}_{3}, 298 \mathrm{~K}\right)$ : $\delta_{\mathrm{C}}=13.0,13.4,16.3,17.8\left(\mathrm{pzCH}_{3}\right), 29.6\left(\mathrm{CMe}_{3}\right), 31.1\left[\mathrm{C}\left(\mathrm{CH}_{3}\right)_{3}\right]$, $57.3(\mathrm{SeC} \equiv \mathrm{C}), 108.1,108.5$ (pzCH), $116.2(\mathrm{SeC} \equiv C), 145.9,146.6$, 153.0, $153.8\left(\mathrm{pzCCH}_{3}\right), 215.7\left(\mathrm{CO},{ }^{1} J_{\mathrm{WC}}=155\right), 239.1\left(\mathrm{~W}=\mathrm{C},{ }^{1} J_{\mathrm{WC}}\right.$ $=106 \mathrm{~Hz}) .{ }^{77} \mathrm{Se}\left\{{ }^{1} \mathrm{H}\right\} \mathrm{NMR}\left(76 \mathrm{MHz}, \mathrm{CDCl}_{3}, 298 \mathrm{~K}\right): \delta_{\mathrm{Se}}=574 . \mathrm{MS}$ (ESI, $m / z$ ): Found: 965.0509. Calcd for $\mathrm{C}_{24} \mathrm{H}_{31} \mathrm{Au}^{11} \mathrm{~B}^{35} \mathrm{ClN}_{6} \mathrm{NaO}_{2}{ }^{80} \mathrm{Se}^{184} \mathrm{~W} \quad[\mathrm{M}+\mathrm{Na}]^{+}$: 965.0530. Anal. Found: $\mathrm{C}, 29.28 ; \mathrm{H}, 3.15 ; \mathrm{N}, 8.27 \%$. Calcd for $\mathrm{C}_{24} \mathrm{H}_{31} \mathrm{AuBCIN} \mathrm{O}_{2} \mathrm{SeW} . \mathrm{CH}_{2} \mathrm{Cl}_{2}$ : C, 29.25; $\mathrm{H}, 3.24 ; \mathrm{N}, 8.19 \%$. Crystals suitable for structure determination were grown by slow evaporation of a $\mathrm{CH}_{2} \mathrm{Cl}_{2} /$ n-hexane mixture. Crystal data for $\mathrm{C}_{24} \mathrm{H}_{31} \mathrm{AuBCIN}_{6} \mathrm{O}_{2} \mathrm{SeW}: M_{\mathrm{w}}=941.58 \mathrm{gmol}^{-1}$ : monoclinic, space group $C 2 / c$ (No. 15), $a=33.8009(6), b=8.10370(10), c=$ 21.5412(3) $\AA, \beta=93.1460(10)^{\circ}, V=5891.51(15) \AA^{3}, Z=8, T=$ $150.0(1) \mathrm{K}, \mu(\mathrm{Cu} \mathrm{K \alpha})=18.848 \mathrm{~mm}^{-1}, D_{\text {calc }}=2.123 \mathrm{Mgm}^{-3}, 16986$ reflections measured $\left(8.222^{\circ} \leq 2 \Theta \leq 147.728^{\circ}\right), 5887$ unique $\left(R_{\text {int }}\right.$ $\left.=0.0224, R_{\text {sigma }}=0.0246\right)$ which were used in all calculations. The final $R_{1}$ was $0.0279(I>2 \sigma(I))$ and $w R_{2}$ was 0.0713 (all data) for 343 refined parameters with 0 restraints. CCDC 1911594.

\section{Synthesis of [WAu( $\left.\left.\mu-\mathrm{CSeC} \equiv \mathrm{CCPh}_{3}\right) \mathrm{Cl}(\mathrm{CO})_{2}\left(\mathrm{Tp}^{*}\right)\right](3 f)$.}

To a mixture of $\mathbf{2 f}(0.010 \mathrm{~g}, 0.011 \mathrm{mmol})$ and [AuCl(SMe 2$)]$ (0.004 g, $0.014 \mathrm{mmol}), \mathrm{CH}_{2} \mathrm{Cl}_{2}(10 \mathrm{~mL})$ was added and the resulting mixture stirred for $30 \mathrm{~min}$ at RT. After this time the volatiles were removed in vacuo and the residue was subjected to column chromatography ( $10 \times 1 \mathrm{~cm}$ silica gel column), eluting initially with petroleum ether $\left(40-60{ }^{\circ} \mathrm{C}\right)$ followed by $1: 1 \mathrm{v} / \mathrm{v}$ petrol $/ \mathrm{CH}_{2} \mathrm{Cl}_{2}$. A slow-moving, bright orange band was collected and the volatiles were removed under reduced pressure to give an orange solid of pure $3 \mathrm{f}(0.009 \mathrm{~g}, 0.008 \mathrm{mmol}, 73 \%)$. IR $\left(\mathrm{CH}_{2} \mathrm{Cl}_{2}, \mathrm{~cm}^{-1}\right)$ : 2013s, $1932 \mathrm{~s} v_{\mathrm{co}} .{ }^{1} \mathrm{H}$ NMR $\left(700 \mathrm{MHz}, \mathrm{CDCl}_{3}, 298\right.$ $\mathrm{K}): \delta_{\mathrm{H}}=1.93\left(\mathrm{~s}, 3 \mathrm{H}, \mathrm{pzCH}_{3}\right), 2.32\left(\mathrm{~s}, 3 \mathrm{H}, \mathrm{pzCH}_{3}\right), 2.37(\mathrm{~s}, 6 \mathrm{H}$, $\left.\mathrm{pzCH}_{3}\right), 2.49\left(\mathrm{~s}, 6 \mathrm{H}, \mathrm{pzCH}_{3}\right), 5.82(\mathrm{~s}, 1 \mathrm{H}, \mathrm{pzCH}), 5.95(\mathrm{~s}, 2 \mathrm{H}$,

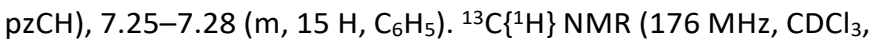
$298 \mathrm{~K}): \delta_{\mathrm{c}}=13.0,13.3,15.7,17.7\left(\mathrm{pzCH}_{3}\right), 64.3(\mathrm{SeC} \equiv \mathrm{C}), 108.1$, $108.5(\mathrm{pzCH}), 112.5(\mathrm{SeC} \equiv C), 127.3\left[\mathrm{C}^{4}\left(\mathrm{C}_{6} \mathrm{H}_{5}\right)\right], 128.3\left[\mathrm{C}^{3,5}\left(\mathrm{C}_{6} \mathrm{H}_{5}\right)\right]$, $129.7\left[\mathrm{C}^{2,6}\left(\mathrm{C}_{6} \mathrm{H}_{5}\right)\right], 144.9\left[\mathrm{C}^{1}\left(\mathrm{C}_{6} \mathrm{H}_{5}\right)\right], 145.9,146.5,152.9,154.0$ $\left(\mathrm{pzCCH}_{3}\right), 215.9\left(\mathrm{CO},{ }^{1} J_{\mathrm{WC}}=155\right), 237.3\left(\mathrm{~W} \equiv \mathrm{C}, 1{ }_{\mathrm{wC}}=106 \mathrm{~Hz}\right)$. ${ }^{77} \mathrm{Se}\left\{{ }^{1} \mathrm{H}\right\} \mathrm{NMR}\left(76 \mathrm{MHz}, \mathrm{CDCl}_{3}, 298 \mathrm{~K}\right): \delta_{\mathrm{se}}=581 . \mathrm{MS}(\mathrm{ESI}, \mathrm{m} / \mathrm{z})$ : Found: 1093.1398. Calcd for $\mathrm{C}_{39} \mathrm{H}_{37} \mathrm{Au}^{11} \mathrm{BN}_{6} \mathrm{O}_{2}{ }^{80} \mathrm{Se}^{184} \mathrm{~W}[\mathrm{M}-\mathrm{Cl}]^{+}$: 1093.1429. Anal. Found: $\mathrm{C}, 41.41 ; \mathrm{H}, 3.19 ; \mathrm{N}, 7.42 \%$. Calcd for $\mathrm{C}_{39} \mathrm{H}_{37} \mathrm{AuBCIN}_{6} \mathrm{O}_{2} \mathrm{SeW}: \mathrm{C}, 41.53 ; \mathrm{H}, 3.31 ; \mathrm{N}, 7.45 \%$. A crystal suitable for structure determination was grown by slow evaporation of a $\mathrm{CH}_{2} \mathrm{Cl}_{2} / n$-hexane solution. Crystal data for $\mathrm{C}_{39} \mathrm{H}_{37} \mathrm{AuBCIN} \mathrm{O}_{2} \mathrm{SeW}: M_{\mathrm{w}}=1127.78 \mathrm{gmol}^{-1}$, monoclinic, space group $P 21 / c$ (No. 14), $a=18.8253(2), b=10.81660(10), c=$ 19.6913(2) $\AA, \beta=104.4410(10)^{\circ}, V=3882.97(7) \AA^{3}, Z=4, T=$ $150.0(1) \mathrm{K}, \mu(\mathrm{Cu} \mathrm{K \alpha})=14.438 \mathrm{~mm}^{-1}, D_{\text {calc }}=1.929 \mathrm{Mgm}^{-3}, 14081$ reflections measured $\left(9.276^{\circ} \leq 2 \Theta \leq 144.252^{\circ}\right), 7548$ unique $\left(R_{\text {int }}=0.0370, R_{\text {sigma }}=0.0484\right)$ which were used in all calculations. The final $R_{1}$ was $0.0498(I>2 \sigma(I))$ and $w R_{2}$ was 0.1483 (all data) for 475 refined parameters with 0 restraints. CCDC 1911595.

Synthesis of $\left[\mathrm{WAu}\left(\mu-\mathrm{CSeC} \equiv \mathrm{CSiPh}_{3}\right) \mathrm{Cl}(\mathrm{CO})_{2}\left(\mathrm{Tp}^{*}\right)\right](3 \mathrm{~g})$. To a flask containing $2 \mathrm{~g}(0.021 \mathrm{~g}, 0.023 \mathrm{mmol})$ and $\left[\mathrm{AuCl}\left(\mathrm{SMe}_{2}\right)\right]$ ( $0.007 \mathrm{~g}, 0.024 \mathrm{mmol}$ ) was added $\mathrm{CH}_{2} \mathrm{Cl}_{2}(5 \mathrm{~mL})$ and the resulting mixture was stirred for $30 \mathrm{~min}$, during which time the orange solution darkened. The solution was filtered through 
diatomaceous earth and the filtrate was dried under reduced pressure to give an orange solid of pure $3 \mathrm{~g}(0.025 \mathrm{~g}, 0.021$ mmol, 95\%). IR $\left(\mathrm{CH}_{2} \mathrm{Cl}_{2}, \mathrm{~cm}^{-1}\right): 2016,1935 v_{\mathrm{co}} .{ }^{1} \mathrm{H}$ NMR (600 $\left.\mathrm{MHz}, \mathrm{CDCl}_{3}, 298 \mathrm{~K}\right): \delta_{\mathrm{H}}=1.84\left(\mathrm{~s}, 3 \mathrm{H}, \mathrm{pzCH}_{3}\right), 2.30\left(\mathrm{~s}, 3 \mathrm{H}, \mathrm{pzCH}_{3}\right)$, $2.36\left(\mathrm{~s}, 6 \mathrm{H}, \mathrm{pzCH}_{3}\right), 2.49\left(\mathrm{~s}, 6 \mathrm{H}, \mathrm{pzCH}_{3}\right), 5.77(\mathrm{~s}, 1 \mathrm{H}, \mathrm{pzCH}), 5.95$ $(\mathrm{s}, 2 \mathrm{H}, \mathrm{pzCH}), 7.37\left[\mathrm{t},{ }^{3} \mathrm{~J}_{\mathrm{HH}}=7.8,6 \mathrm{H},\left[\mathrm{H}^{2,6}\left(\mathrm{C}_{6} \mathrm{H}_{5}\right)\right], 7.43\left[\mathrm{t},{ }^{3}\right]_{\mathrm{HH}}=\right.$ $7.8,6 \mathrm{H},\left[\mathrm{H}^{4}\left(\mathrm{C}_{6} \mathrm{H}_{5}\right)\right], 7.67\left[\mathrm{~d},{ }^{3} J_{\mathrm{HH}}=7.2,6 \mathrm{H},\left[\mathrm{t},{ }^{3} J_{\mathrm{HH}}=7.8 \mathrm{~Hz}, 6 \mathrm{H}\right.\right.$, $\left[\mathrm{H}^{3,5}\left(\mathrm{C}_{6} \mathrm{H}_{5}\right)\right] .{ }^{13} \mathrm{C}\left\{{ }^{1} \mathrm{H}\right\} \mathrm{NMR}\left(151 \mathrm{MHz}, \mathrm{CDCl}_{3}, 298 \mathrm{~K}\right): \delta_{\mathrm{C}}=13.0$, 13.4, 15.4, $17.7\left(\mathrm{pzCH}_{3}\right), 89.2(\mathrm{SeC} \equiv \mathrm{C}), 108.1,108.5(\mathrm{pzCH})$, $110.0(\mathrm{SeC} \equiv C), 128.3 \quad\left[\mathrm{C}^{2,6}\left(\mathrm{C}_{6} \mathrm{H}_{5}\right)\right], 130.4 \quad\left[\mathrm{C}^{4}\left(\mathrm{C}_{6} \mathrm{H}_{5}\right)\right], 133.0$ $\left[\mathrm{C}^{1}\left(\mathrm{C}_{6} \mathrm{H}_{5}\right)\right], 136.1\left[\mathrm{C}^{3,5}\left(\mathrm{C}_{6} \mathrm{H}_{5}\right)\right], 146.0,146.5,152.9,154.2$ $\left(\mathrm{pzCCH}_{3}\right), 215.3\left(\mathrm{CO},{ }^{1} J_{\mathrm{Wc}}=154\right), 234.6\left(\mathrm{~W} \equiv \mathrm{C},{ }^{1} J_{\mathrm{Wc}}=106 \mathrm{~Hz}\right)$. ${ }^{77} \mathrm{Se}\left\{{ }^{1} \mathrm{H}\right\}$ NMR $\left(76 \mathrm{MHz}, \mathrm{CDCl}_{3}, 298 \mathrm{~K}\right): \delta_{\mathrm{se}}=597 . \mathrm{MS}(\mathrm{ESI}, \mathrm{m} / \mathrm{z})$ : Found: 1109.1188. Calcd for $\mathrm{C}_{38} \mathrm{H}_{37} \mathrm{Au}^{11} \mathrm{~B}^{35} \mathrm{~N}_{6} \mathrm{O}_{2}{ }^{80} \mathrm{SeSi}^{184} \mathrm{~W}$ [M$\mathrm{Cl}^{+}:$1109.1196. Anal. Found: $\mathrm{C}, 40.05 ; \mathrm{H}, 3.34 ; \mathrm{N}, 7.18 \%$. Calcd for $\mathrm{C}_{38} \mathrm{H}_{37} \mathrm{AuBCIN}_{6} \mathrm{O}_{2} \mathrm{SeSiW}$ : C, 39.90; $\mathrm{H}, 3.26 ; \mathrm{N}, 7.35 \%$. A crystal suitable for structure determination was grown by slow evaporation of a $\mathrm{CH}_{2} \mathrm{Cl}_{2} / n$-hexane solution. Crystal data for $\mathrm{C}_{38} \mathrm{H}_{37} \mathrm{AuBClN}{ }_{6} \mathrm{O}_{2} \mathrm{SeSiW}: M_{\mathrm{w}}=1143.86 \mathrm{gmol}^{-1}$, monoclinic, space group $P 2{ }_{1} / c \quad$ (no. 14$), a=18.8932(3) \AA, b=$ 10.8591(2) $\AA, c=\quad 19.9439(3) \AA \AA \quad \beta=\quad 103.0180(10)^{\circ}, V=$ 3986.59(12) $\AA^{3}, Z=4, T=150.0(1) \mathrm{K}, \mu(\mathrm{Cu} \mathrm{K \alpha})=14.352 \mathrm{~mm}^{-}$ $1, D_{\text {calc }}=1.906 \mathrm{Mgm}^{-3}, 13502$ reflections measured $\left(9.102^{\circ} \leq 2 \Theta\right.$ $\left.\leq 133.182^{\circ}\right), 6990$ unique $\left(R_{\text {int }}=0.0356, R_{\text {sigma }}=0.0581\right)$ which were used in all calculations. The final $R_{1}$ was $0.0460(I>2 \sigma(I))$ and $w R_{2}$ was 0.1303 (all data) for 491 refined parameters with 119 restraints. CCDC 1911596.

Synthesis of $\left[\mathrm{WAu}\left(\mu-\mathrm{CSeC} \equiv \mathrm{CGePh}_{3}\right) \mathrm{Cl}(\mathrm{CO})_{2}\left(\mathrm{Tp}^{*}\right)\right]$ (3h). To a flask containing $2 \mathrm{~h}(0.038 \mathrm{~g}, 0.040 \mathrm{mmol})$ and $\left[\mathrm{AuCl}\left(\mathrm{SMe}_{2}\right)\right.$ ] ( $0.012 \mathrm{~g}, 0.041 \mathrm{mmol}$ ) was added $\mathrm{CH}_{2} \mathrm{Cl}_{2}(5 \mathrm{~mL})$ and the resulting mixture was stirred for $30 \mathrm{~min}$, during which time the orange solution darkened. The solution was filtered through diatomaceous earth and the filtrate was dried under reduced pressure to give an orange solid of pure $3 \mathrm{~h}(0.040 \mathrm{~g}, 0.034$ mmol, 85\%). IR $\left(\mathrm{CH}_{2} \mathrm{Cl}_{2}, \mathrm{~cm}^{-1}\right): 2015,1935 v_{\mathrm{co}}{ }^{1} \mathrm{H}$ NMR (600 $\left.\mathrm{MHz}, \mathrm{CDCl}_{3}, 298 \mathrm{~K}\right): \delta_{\mathrm{H}}=1.86\left(\mathrm{~s}, 3 \mathrm{H}, \mathrm{pzCH}_{3}\right), 2.30\left(\mathrm{~s}, 3 \mathrm{H}, \mathrm{pzCH}_{3}\right)$, $2.36\left(\mathrm{~s}, 6 \mathrm{H}, \mathrm{pzCH}_{3}\right), 2.50\left(\mathrm{~s}, 6 \mathrm{H}, \mathrm{pzCH}_{3}\right), 5.78(\mathrm{~s}, 1 \mathrm{H}, \mathrm{pzCH}), 5.95$ (s, $2 \mathrm{H}, \mathrm{pzCH}), 7.41\left[\mathrm{~m}, 6 \mathrm{H}, \mathrm{H}^{2,6}\left(\mathrm{C}_{6} \mathrm{H}_{5}\right)\right], 7.37-7.41[\mathrm{~m}, 9 \mathrm{H}$, $\left.\mathrm{H}^{3,4,5}\left(\mathrm{C}_{6} \mathrm{H}_{5}\right)\right] .{ }^{13} \mathrm{C}\left\{{ }^{1} \mathrm{H}\right\}$ NMR $\left(151 \mathrm{MHz}, \mathrm{CDCl}_{3}, 298 \mathrm{~K} \delta\right): \delta_{\mathrm{C}}=13.0$, 13.3, 15.4, $17.7\left(\mathrm{pzCH}_{3}\right), 86.3(\mathrm{SeC} \equiv \mathrm{C}), 108.1,108.5(\mathrm{pzCH})$, $109.5(\mathrm{SeC} \equiv C), \quad 128.7 \quad\left[\mathrm{C}^{2,6}\left(\mathrm{C}_{6} \mathrm{H}_{5}\right)\right], 129.9 \quad\left[\mathrm{C}^{4}\left(\mathrm{C}_{6} \mathrm{H}_{5}\right)\right], 134.7$ $\left[\mathrm{C}^{1}\left(\mathrm{C}_{6} \mathrm{H}_{5}\right)\right], 135.0\left[\mathrm{C}^{3,5}\left(\mathrm{C}_{6} \mathrm{H}_{5}\right)\right], 145.9,146.4,152.8,154.2$ $\left(\mathrm{pzCCH}_{3}\right), 215.4\left(\mathrm{CO},{ }^{1} J_{\mathrm{WC}}=156\right), 235.7\left(\mathrm{~W} \equiv \mathrm{C},{ }^{1}{ }_{\mathrm{WC}}=107 \mathrm{~Hz}\right)$. ${ }^{77} \mathrm{Se}\left\{{ }^{1} \mathrm{H}\right\}$ NMR $\left(76 \mathrm{MHz}, \mathrm{CDCl}_{3}, 298 \mathrm{~K}\right): \delta_{\mathrm{se}}=599 . \mathrm{MS}(\mathrm{ESI}, \mathrm{m} / \mathrm{z})$ : Found: 1153.0663. Calcd for $\mathrm{C}_{38} \mathrm{H}_{37} \mathrm{Au}^{11} \mathrm{~B}^{35} \mathrm{GeN}_{6} \mathrm{O}_{2}{ }^{80} \mathrm{Se}^{184} \mathrm{~W}[\mathrm{M}-$ $\mathrm{Cl}^{+}$: 1153.0648. Anal. Found: C, 38.51; H, 3.20; N, 6.99\%. Calcd for $\mathrm{C}_{38} \mathrm{H}_{37} \mathrm{AuBClGeN} \mathrm{O}_{2} \mathrm{SeW}: \mathrm{C}, 38.41 ; \mathrm{H}, 3.14 ; \mathrm{N}, 7.07 \%$. Crystals suitable for structure determination were grown by slow evaporation of a $\mathrm{CH}_{2} \mathrm{Cl}_{2} / n$-hexane mixture. Crystal data for $\mathrm{C}_{38} \mathrm{H}_{37} \mathrm{AuBClGeN} \mathrm{O}_{2} \mathrm{SeW}: M_{\mathrm{w}}=1188.36 \mathrm{gmol}^{-1}$, monoclinic, space group $P 2_{1} / c$ (no. 14), $a=18.9006(3), b=10.8913(2), c=$ 19.9702(3) $\AA, \beta=102.792(2)^{\circ}, V=4008.88(12) \AA^{3}, Z=4, T=$ $150.0(1) \mathrm{K}, \mu(\mathrm{Cu} \mathrm{K} \alpha)=14.793 \mathrm{~mm}^{-1}, D_{\text {calc }}=1.969 \mathrm{Mgm}^{-3}, 30204$ reflections measured $\left(9.082^{\circ} \leq 2 \Theta \leq 147.628^{\circ}\right), 8049$ unique $\left(R_{\text {int }}\right.$ $\left.=0.0433, R_{\text {sigma }}=0.0397\right)$ which were used in all calculations. The final $R_{1}$ was $0.0389(I>2 \sigma(I))$ and $w R_{2}$ was 0.1146 (all data) for 463 refined parameters with 72 restraints. CCDC 1911597.
Synthesis of $\left[\mathrm{W}\left(\equiv \mathrm{CSeC} \equiv \mathrm{CAuPPh}_{3}\right)(\mathrm{CO})_{2}\left(\mathrm{Tp}^{*}\right)\right]$ (4a). To a solution of $2 \mathrm{a}(100 \mathrm{mg}, 0.138 \mathrm{mmol})$ and $\left[\mathrm{AuCl}\left(\mathrm{PPh}_{3}\right)\right](69 \mathrm{mg}$, $0.139 \mathrm{mmol})$ in $\mathrm{CH}_{2} \mathrm{Cl}_{2}(5 \mathrm{~mL})$ was added $\left[\mathrm{NBu}_{4}\right] \mathrm{F}(0.27 \mathrm{~mL}, 1.0$ $\mathrm{M}$ in THF, $0.270 \mathrm{mmol}$ ). The resulting bright orange solution was allowed to stir for $3 \mathrm{~h}$, after which time ethanol $(10 \mathrm{~mL})$ was added to the solution mixture. This was concentrated under reduced pressure to precipitate an orange solid which was filtered, washed with ethanol $(3 \times 5 \mathrm{~mL})$ and pentane $(3 \times 5 \mathrm{~mL})$ to yield an orange-brown solid of pure $4 \mathrm{a}(0.094 \mathrm{~g}, 0.085 \mathrm{mmol}$, $61 \%)$. IR $\left(\mathrm{CH}_{2} \mathrm{Cl}_{2}, \mathrm{~cm}^{-1}\right): 1982,1890 v_{\mathrm{CO}} .{ }^{1} \mathrm{H} \mathrm{NMR}(600 \mathrm{MHz}$, $\left.\mathrm{CDCl}_{3}, 298 \mathrm{~K}\right): \delta_{\mathrm{H}}=2.31\left(\mathrm{~s}, 3 \mathrm{H}, \mathrm{pzCH}_{3}\right), 2.35\left(\mathrm{~s}, 6 \mathrm{H}, \mathrm{pzCH}_{3}\right), 2.41$ (s, $\left.3 \mathrm{H}, \mathrm{pzCH}_{3}\right), 2.63\left(\mathrm{~s}, 6 \mathrm{H}, \mathrm{pzCH}_{3}\right), 5.75(\mathrm{~s}, 1 \mathrm{H}, \mathrm{pzCH}), 5.86(\mathrm{~s}, 2$ $\mathrm{H}, \mathrm{pzCH}), 7.44\left[\mathrm{~m}, 6 \mathrm{H}, \mathrm{H}^{2,6}\left(\mathrm{C}_{6} \mathrm{H}_{5}\right)\right], 7.50\left[\mathrm{~m}, 3 \mathrm{H}, \mathrm{H}^{4}\left(\mathrm{C}_{6} \mathrm{H}_{5}\right)\right], 7.53$ $\left[\mathrm{m}, 6 \mathrm{H}, \mathrm{H}^{3,5}\left(\mathrm{C}_{6} \mathrm{H}_{5}\right)\right] .{ }^{13} \mathrm{C}\left\{{ }^{1} \mathrm{H}\right\} \mathrm{NMR}\left(151 \mathrm{MHz}, \mathrm{CDCl}_{3}, 298 \mathrm{~K}\right): \delta_{\mathrm{C}}=$ 13.0, 15.6, $17.3\left(\mathrm{pzCH}_{3}\right), 73.5\left(\mathrm{~d},{ }^{3} \mathrm{~J}_{\mathrm{CP}}=27.5, \mathrm{SeC} \equiv \mathrm{CAuP}\right), 106.7$, $107.0(\mathrm{pzCH}), 129.4\left[\mathrm{~d},{ }^{3} J_{\mathrm{PC}}=11.3, \mathrm{C}^{2,6}\left(\mathrm{C}_{6} \mathrm{H}_{5}\right)\right], 130.1\left[\mathrm{~d},{ }^{1} J_{\mathrm{PC}}=\right.$ $\left.55.9 \mathrm{~Hz}, \mathrm{C}^{1}\left(\mathrm{C}_{6} \mathrm{H}_{5}\right)\right], 131.8\left[\mathrm{C}^{4}\left(\mathrm{C}_{6} \mathrm{H}_{5}\right)\right], 134.6\left[\mathrm{~d},{ }^{4} J_{\mathrm{PC}}=13.9 \mathrm{~Hz}\right.$, $\left.\mathrm{C}^{3,5}\left(\mathrm{C}_{6} \mathrm{H}_{5}\right)\right], 144.5,145.4,151.4\left(\mathrm{~d},{ }^{3} J_{\mathrm{CP}}=143.0, \mathrm{CAuP}\right), 152.7$, $152.9\left(\mathrm{pzCCH}_{3}\right), 223.7\left(\mathrm{CO},{ }^{1} J_{\mathrm{WC}}=165\right), 243.5\left(\mathrm{~W} \equiv \mathrm{C},{ }^{1} J_{\mathrm{WC}}=222\right.$ $\mathrm{Hz}) .{ }^{31} \mathrm{P}\left\{{ }^{1} \mathrm{H}\right\} \mathrm{NMR}\left(162 \mathrm{MHz}, \mathrm{CDCl}_{3}, 298 \mathrm{~K}\right): \delta_{\mathrm{P}}=41.5 .{ }^{77} \mathrm{Se}\left\{{ }^{1} \mathrm{H}\right\}$ NMR (76 MHz, $\left.\mathrm{CDCl}_{3}, 298 \mathrm{~K}\right): \delta_{\mathrm{se}}=512$. MS $(\mathrm{ESI}, \mathrm{m} / z)$ : Found: 1113.1226. Calcd for $\mathrm{C}_{38} \mathrm{H}_{38} \mathrm{Au}^{11} \mathrm{~B}^{35} \mathrm{~N}_{6} \mathrm{O}_{2} \mathrm{P}^{80} \mathrm{Se}^{184} \mathrm{~W} \quad[\mathrm{M}+\mathrm{H}]^{+}$: 1113.1244. Anal. Found: C, 40.96; H, 3.43; N, 7.44\%. Calcd for $\mathrm{C}_{38} \mathrm{H}_{37} \mathrm{AuBN}_{6} \mathrm{O}_{2}$ PSeW: $\mathrm{C}, 41.07 ; \mathrm{H}, 3.36 ; \mathrm{N}, 7.56 \%$. Crystals suitable for structure determination were grown by slow evaporation of a chloroform/ethanol mixture. Crystal data for $\mathrm{C}_{38} \mathrm{H}_{38} \mathrm{AuBN}_{6} \mathrm{O}_{2}$ PSeW: $M_{\mathrm{w}}=1112.30 \mathrm{gmol}^{-1}$, monoclinic, space group $P 21 / n$ (No. 14), $a=19.3636(9), b=11.7193(4), c=$ 19.6341(9) $\AA, \quad \beta=115.946(6)^{\circ}, \quad V=4006.4(3) \AA^{3}, \quad Z=4, \quad T=$ $150.0(1) \mathrm{K}, \mu(\mathrm{Cu} \mathrm{K} \alpha)=13.749 \mathrm{~mm}^{-1}, D_{\text {calc }}=1.844 \mathrm{Mgm}^{-3}, 24703$ reflections measured $\left(8.552^{\circ} \leq 2 \Theta \leq 145.402^{\circ}\right), 7839$ unique $\left(R_{\text {int }}\right.$ $\left.=0.0494, R_{\text {sigma }}=0.0540\right)$ which were used in all calculations. The final $R_{1}$ was $0.0535(I>2 \sigma(l))$ and $w R_{2}$ was 0.1558 (all data) for 466 refined parameters with no restraints. CCDC 1911598.

Synthesis of $\left[\mathrm{W}\left(\equiv \mathrm{CSeC} \mathrm{CAuPC}_{3}\right)(\mathrm{CO})_{2}\left(\mathrm{Tp}^{*}\right)\right](4 \mathrm{~b})$. To a solution of $2 \mathrm{a}(100 \mathrm{mg}, 0.138 \mathrm{mmol})$ and $\mathrm{AuCl}\left(\mathrm{PCy}_{3}\right)(71 \mathrm{mg}$, $0.138 \mathrm{mmol})$ in $\mathrm{CH}_{2} \mathrm{Cl}_{2}(5 \mathrm{~mL})$, was added [ $\left.\mathrm{NBu}_{4}\right] \mathrm{F}(0.27 \mathrm{~mL}, 1.0$ $\mathrm{M}$ in THF, $0.270 \mathrm{mmol}$ ). The resulting bright orange solution was allowed to stir overnight, after which time ethanol $(10 \mathrm{~mL})$ was added to the solution mixture. This was concentrated under reduced pressure to precipitate out an orange-brown solid which was filtered, washed with ethanol $(3 \times 5 \mathrm{~mL})$ and pentane $(3 \times 5 \mathrm{~mL})$ to yield an orange-brown solid of pure $4 \mathrm{~b}(0.095 \mathrm{~g}$, $0.084 \mathrm{mmol}, 61 \%)$. IR $\left(\mathrm{CH}_{2} \mathrm{Cl}_{2}, \mathrm{~cm}^{-1}\right)$ : 1981s, 1889s $v_{\mathrm{cO}} .{ }^{1} \mathrm{H} \mathrm{NMR}$ $\left(600 \mathrm{MHz}, \mathrm{CDCl}_{3}, 298 \mathrm{~K}\right): \delta_{\mathrm{H}}=1.26\left(\mathrm{br}, 9 \mathrm{H}, \mathrm{C}_{6} \mathrm{H}_{11}\right), 1.46(\mathrm{br}, 6 \mathrm{H}$, $\left.\mathrm{C}_{6} \mathrm{H}_{11}\right), 1.72\left(\mathrm{br}, 3 \mathrm{H}, \mathrm{C}_{6} \mathrm{H}_{11}\right), 1.84\left(\mathrm{br}, 6 \mathrm{H}, \mathrm{C}_{6} \mathrm{H}_{11}\right), 1.97(\mathrm{br}, 9 \mathrm{H}$, $\left.\mathrm{C}_{6} \mathrm{H}_{11}\right), 2.31\left(\mathrm{~s}, 3 \mathrm{H}, \mathrm{pzCH}_{3}\right), 2.34\left(\mathrm{~s}, 6 \mathrm{H}, \mathrm{pzCH}_{3}\right), 2.40(\mathrm{~s}, 3 \mathrm{H}$, $\left.\mathrm{pzCH}_{3}\right), 2.62(\mathrm{~s}, 6 \mathrm{H}, \mathrm{pzCH}$ ) , $5.74(\mathrm{~s}, 1 \mathrm{H}, \mathrm{pzCH}), 5.85(\mathrm{~s}, 2 \mathrm{H}$, pzCH). ${ }^{13} \mathrm{C}\left\{{ }^{1} \mathrm{H}\right\} \mathrm{NMR}\left(151 \mathrm{MHz}, \mathrm{CDCl}_{3}, 298 \mathrm{~K}\right): \delta_{\mathrm{C}}=13.0,15.6$, $17.4\left(\mathrm{pzCH}_{3}\right), 72.9\left(\mathrm{~d},{ }^{3} J_{\mathrm{CP}}=25.7, \mathrm{SeC} \equiv \mathrm{C}\right), 106.7,106.9(\mathrm{pzCH})$, $144.4,145.4,152.8,152.9\left(\mathrm{pzCCH}_{3}\right), 156.3\left(\mathrm{~d},{ }^{3} J_{\mathrm{CP}}=132.9\right.$, इCAuP $), 223.8\left(\mathrm{CO},{ }^{1} J_{\mathrm{WC}}=166\right), 245.1\left(\mathrm{~W} \equiv \mathrm{C},{ }^{1} J_{\mathrm{WC}}=222 \mathrm{~Hz}\right)$. ${ }^{31} \mathrm{P}\left\{{ }^{1} \mathrm{H}\right\} \mathrm{NMR}\left(162 \mathrm{MHz}, \mathrm{CDCl}_{3}, 298 \mathrm{~K}\right): \delta_{\mathrm{P}}=55.9 .{ }^{77} \mathrm{Se}\left\{{ }^{1} \mathrm{H}\right\} \mathrm{NMR}$ (76 $\mathrm{MHz}, \mathrm{CDCl}_{3}, 298 \mathrm{~K}$ ): $\delta_{\mathrm{se}}=513$. MS $(\mathrm{ESI}, \mathrm{m} / z)$ : Found: 1130.2554. Calcd for $\mathrm{C}_{38} \mathrm{H}_{55} \mathrm{Au}^{11} \mathrm{BN}_{6} \mathrm{O}_{2} \mathrm{P}^{80} \mathrm{Se}^{184} \mathrm{~W}$ [M] 1130.2581. Anal. Found: $\mathrm{C}, 40.32 ; \mathrm{H}, 4.82 ; \mathrm{N}, 7.29 \%$. Calcd for $\mathrm{C}_{38} \mathrm{H}_{55} \mathrm{AuBN}_{6} \mathrm{O}_{2}$ PSeW: C, 40.41; $\mathrm{H}, 4.91 ; \mathrm{N}, 7.44 \%$. 


\section{Conflicts of interest}

There are no conflicts to declare.

\section{Acknowledgements}

We gratefully acknowledge the Australian Research Council (DP170102695 and DP190100723) for funding and the Australian National University for the award of a doctoral scholarship to C.S.O.

\section{Notes and references}

1 (a) D. Xiang, X. L. Wang, C. C. Jia, T. Lee and X. F. Guo, Chem. Rev., 2016, 116, 4318-4440; (b) S. Marques-Gonzalez and P. J. Low, Aust. J. Chem., 2016, 69, 244-253; (c) M. I. Bruce and P. J. Low, Adv. Organomet. Chem., 2004, 50, 180-444.

2 (a) B. J. Frogley, T. L. Genet, A. F. Hill and C. S. Onn, Dalton Trans., 2019, 48, DOI: 10.1039/C9DT01504C; (b) B. J. Frogley and A. F. Hill, Chem. Commun., 2018, 54, 12373-12376; (c) B. J. Frogley and A. F. Hill, Chem. Commun., 2018, 54, 7649 7652; (c) B. J. Frogley and A. F. Hill, Chem. Commun., 2018, 54, 2126 - 2129; (d) B. J. Frogley, A. F. Hill, R. A. Manzano and M. Sharma, Chem. Commun., 2018, 54, 1702 1705; (e) A. F. Hill, R. A. Manzano and J. S. Ward, Dalton Trans., 2018, 47, 14621 - 14629; (f) A. F. Hill, R. A. Manzano, M. Sharma and J. S. Ward, Organometallics, 2015, 34, 361 365; (g) A. L. Colebatch and A. F. Hill, Dalton Trans., 2017, 46, 4355 - 4365; (h) A. L. Colebatch, Y.-S. Han, A. F. Hill, M. Sharma, R. Shang and J. S. Ward, Chem. Commun., 2017, 53, 1832 - 1835; (i) A. L. Colebatch and A. F. Hill, Organometallics, 2016, 35, $2249-2255$.

3 R. Ezquerra, S. G. Eaves, S Bock, B. W. Skelton, F. PérezMurano, P. Cea, S. Martín and P. J. Low, J. Mater. Chem. C, 2019, Adv. Article, DOI: 10.1039/C9TC01305A and refs. therein.

4 (a) G. R. Clark, C. M. Cochrane, W. R. Roper and L. J. Wright, J. Organomet. Chem., 1980, 199, C35-C38; (b) A. F. Hill, W. R. Roper, J. M. Waters and A. H. Wright, J. Am. Chem. Soc., 1983, 105, $5930-5940$.

5 (a) G. A. Carriedo, J. A. K. Howard, K. Marsden, F. G. A. Stone and P. Woodward, J. Chem. Soc., Dalton Trans., 1984, 15891595; (b) M. Green, J. A. K. Howard, A. P. James, C. M. Nunn and F. G. A. Stone, J. Chem. Soc., Chem. Commun., 1984, 11131114; (c) S. H. F. Becke, M. D. Bermúdez, N. H. Tran-Huy, J. A. K. Howard, O. Johnson and F. G. A. Stone, J. Chem. Soc., Dalton Trans., 1987, 1229-1234; (d) M. Green, J. A. K. Howard, A. P. James, C. M. Nunn and F. G. A. Stone, J. Chem. Soc., Dalton Trans., 1987, 61-72; (e) F.-E. Baumann, J. A. K. Howard, O. Johnson and F. G. A. Stone, J. Chem. Soc., Dalton Trans., 1987, 2661-2667; (f) D. D. Devore, C. Emmerich, J. A. K. Howard and F. G. A. Stone, J. Chem. Soc., Dalton Trans., 1989, 797-807; (g) S. J. Crennell, D. D. Devore, S. J. B. Henderson, J. A. K. Howard and F. G. A. Stone, J. Chem. Soc., Dalton Trans., 1989, 13631374; (h) P. K. Byers, N. Carr and F. G. A. Stone, J. Chem. Soc., Dalton Trans., 1990, 3701-3708; (i) M. C. Gimeno and F. G. A. Stone, J. Chem. Soc., Dalton Trans., 1990, 2239-2245; (j) N. Carr, M. C. Gimeno and F. G. A. Stone, J. Chem. Soc., Dalton Trans., 1990, 2247-2252; (k) S. J. Dossett, I. J. Hart, M. U. Pilotti and F. G. A. Stone, J. Chem. Soc., Dalton Trans., 1990, 3489-3497; (I) J.-L. Cabioch, S. J. Dossett, I. J. Hart, M. U. Pilotti and F. G. A. Stone, J. Chem. Soc., Dalton Trans., 1991, 519-527; (m) J. E. Goldberg, D. F. Mullica, E. L. Sappenfield and F. G. A. Stone, J. Chem. Soc., Dalton Trans., 1992, 2495-2502.
6 (a) G. A. Carriedo, V. Riera, G. Sánchez and X. Solans, J. Chem. Soc., Dalton Trans., 1988, 1957-1962; (b) G. A. Carriedo, V. Riera, G. Sánchez, X. Solans and M. Labrador, J. Organomet. Chem., 1990, 391, 431-437; (c) C. E. Strasser, S. Cronje and H. G. Raubenheimer, New J. Chem., 2010, 34, 458-469.

7 X. Zhou, Y. Li, Y. Shao, Y. Hua, H. Zhang, Y.-M. Lin and H. Xia, Organometallics, 2018, 37, 1788-1794.

8 (a) E. S. Borren, A. F. Hill, R. Shang, M. Sharma and A. C. Willis, J. Am. Chem. Soc., 2013, 135, 4942-4945; (b) A. Reinholdt, J. Bendix, A. F. Hill and R. A. Manzano, Dalton Trans., 2018, 47, 14893-14896.

9 (a) L. M. Caldwell, A. F. Hill, A. D. Rae and A. C. Willis, Organometallics, 2008, 27, 341-345; (b) L. M. Caldwell, A. F. Hill, J. Wagler and A. C. Willis, Dalton Trans., 2008, 3538-3541; (c) L. M. Caldwell, R. L. Cordiner, A. F. Hill and J. Wagler, Organometallics, 2010, 29, 1526-1529.

10 M. A. Cinellu in Modern Gold Catalyzed Synthesis Eds A. S. K. Hashmi and F. D. Toste, 2012, Chapter 6, pp 153 - 173, WileyVCH Verlag GmbH \& Co, Weinheim, Germany.

11 (a) K. Klauke, I. Gruber, T.-O. Knedel, L. Schmolke, J. Barthel, H. Breitzke, G. Buntkowsky and C. Janiak, Organometallics, 2018, 37, 298 - 308; (b) S. E. Durran, M. R. Elsegood and M. B. Smith, New J. Chem., 2002, 26, $1402-1408$.

12 K. C. Dash and H. Schmidbaur, Chem. Ber., 1973, 106, $1221-$ 1225.

13 L. M. Caldwell, Adv. Organomet. Chem., 2008, 56, 1-94.

14 (a) S. Husebye, E. A. Meyers, R. A. Zingaro, A. L. Braga, J. V. Comasseto and N. Petragnani, Acta Crystallogr. Sect. C, 1986, 42, 1789-1792; (b) D. B. Werz and R. Gleiter, J. Org. Chem., 2003, 68, 9400-9405; (c) K. Yamane, S. Hayashi, W. Nakanishi, T. Sasamori and N. Tokitoh, Polyhedron, 2008, 27, 2478-2486; (d) K. Yamane, S. Hayashi, W. Nakanishi, T. Sasamori and N. Tokitoh, Polyhedron, 2008, 27, 3557-3566; (e) A. Lari, R. Gleiter and F. Rominger, Eur. J. Org. Chem., 2009, 2009, 22672274; (f) S. Thanna, C. M. Goins, S. E. Knudson, R. A. Slayden, D. R. Ronning and S. J. Sucheck, J. Org. Chem., 2017, 82, 38443854.

15 M. R. Awang, G. A. Carriedo, J. A. K. Howard, K. A. Mead, I. Moore, C. M. Nunn and F. G. A. Stone, J. Chem. Soc., Chem. Commun., 1983, 964-966.

16 (a) D. J. Gorin, B. D. Sherry and F. D. Toste, Chem. Rev., 2008, 108, 3351-3378; (b) T. C. Boorman and I. Larrosa, Chem. Soc. Rev., 2011, 40, 1910-1925; (c) W. Y. Man, S. Bock, N. N. Zaitseva, M. I. Bruce and P. J. Low, J. Organomet. Chem., 2011, 696, 2172-2176; (d) H. Peng, Y. Xi, N. Ronaghi, B. Dong, N. G. Akhmedov and X. Shi, J. Am. Chem. Soc., 2014, 136, 1317413177.

17 CrysAlis PRO, Agilent Technologies Ltd, Yarnton, Oxfordshire, England, 2014.

18 G. M. Sheldrick, Acta Crystallogr. Sect. C: Cryst. Struct. Commun., 2015, 71, 3-8.

19 L. Farrugia, J. Appl. Crystallogr., 2012, 45, 849-854.

20 O. V. Dolomanov, L. J. Bourhis, R. J. Gildea, J. A. K. Howard and H. Puschmann, J. Appl. Crystallogr., 2009, 42, 339-341.

21 C. F. Macrae, I. J. Bruno, J. A. Chisholm, P. R. Edgington, P. McCabe, E. Pidcock, L. Rodriguez-Monge, R. Taylor, J. van de Streek and P. A. Wood, J. Appl. Crystallogr., 2008, 41, 466-470.

22 R. Uson, A. Laguna, M. Laguna, D. A. Briggs, H. H. Murray and J. P. F. Jr., in Inorg. Synth., Ed. H. D. Kaesz, 2007, ch. 17.

23 T. N. Hooper, C. P. Butts, M. Green, M. F. Haddow, J. E. McGrady and C. A. Russell, Chem. Eur. J., 2009, 15, 1219612200.

Table of Contents Text

Gold plating carbynes - The incorporation of gold(I) centres, either terminal or bridging, into alkynylselenolatocarbynes 
provides models for how such metallated carbon-wires might bind to metal surfaces.

Table of Contents Graphic

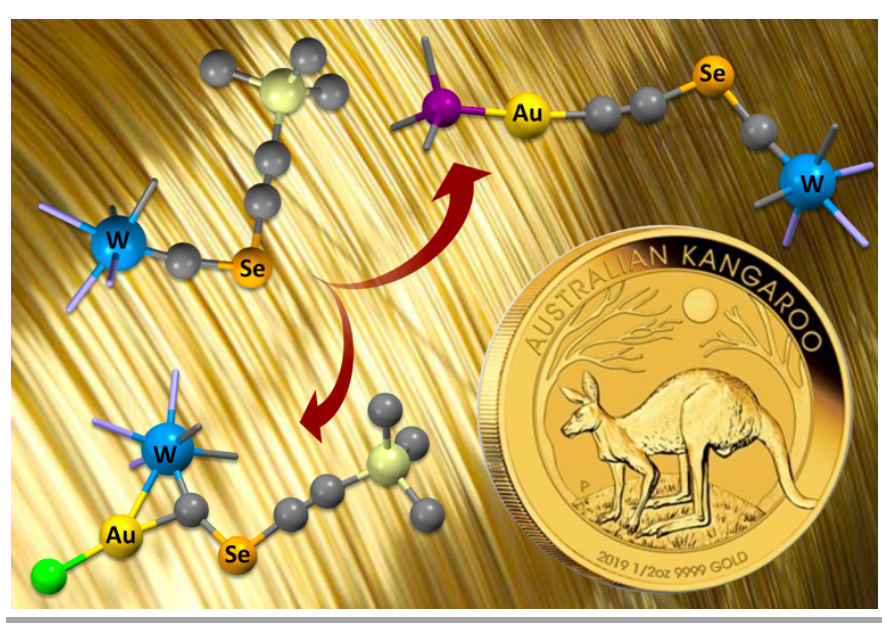

